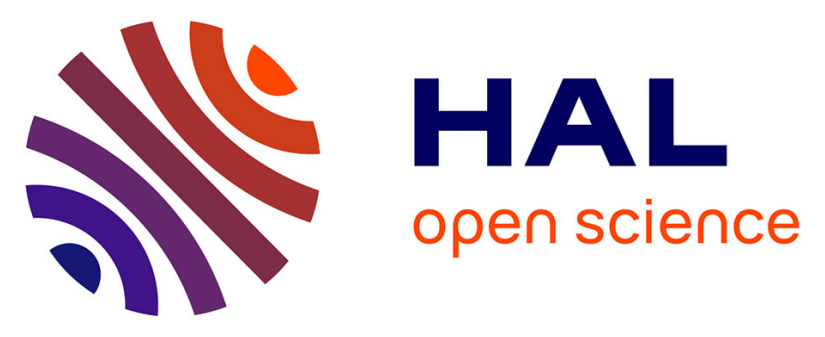

\title{
Benefits and drawbacks of osmotic adjustment in Propionibacterium freudenreichii
}

Floriane Gaucher, Sylvie Bonnassie, Houem Rabah, Pauline Leverrier, Sandrine Pottier, Julien Jardin, Valérie Briard-Bion, Pierre Marchand, Romain Jeantet, Philippe Blanc, et al.

\section{To cite this version:}

Floriane Gaucher, Sylvie Bonnassie, Houem Rabah, Pauline Leverrier, Sandrine Pottier, et al.. Benefits and drawbacks of osmotic adjustment in Propionibacterium freudenreichii. Journal of Proteomics, 2019, 204, pp.103400. 10.1016/j.jprot.2019.103400 . hal-02150444

\section{HAL Id: hal-02150444 https://hal-univ-rennes1.archives-ouvertes.fr/hal-02150444}

Submitted on 12 Jun 2019

HAL is a multi-disciplinary open access archive for the deposit and dissemination of scientific research documents, whether they are published or not. The documents may come from teaching and research institutions in France or abroad, or from public or private research centers.
L'archive ouverte pluridisciplinaire HAL, est destinée au dépôt et à la diffusion de documents scientifiques de niveau recherche, publiés ou non, émanant des établissements d'enseignement et de recherche français ou étrangers, des laboratoires publics ou privés. 


\title{
Benefits and drawbacks of osmotic adjustment in Propionibacterium freudenreichii
}

\author{
Floriane Gaucher ${ }^{\mathrm{a}, \mathrm{b}}$, Sylvie Bonnassie ${ }^{\mathrm{a}, \mathrm{c}}$, Houem Rabah ${ }^{\mathrm{a}, \mathrm{d}}$, Pauline Leverrier ${ }^{\mathrm{e}}$, Sandrine Pottier ${ }^{\mathrm{f}}$, \\ Julien Jardin $^{\mathrm{a}}$, Valérie Briard-Bion ${ }^{\mathrm{a}}$, Pierre Marchand ${ }^{\mathrm{b}}$, Romain Jeantet ${ }^{\mathrm{a}}$, Philippe Blanc ${ }^{\mathrm{b}}$, \\ Gwénaël Jan ${ }^{\mathrm{a}, *}$ \\ ${ }^{\text {a } U M R ~ S T L O, ~ A g r o c a m p u s ~ O u e s t, ~ I N R A, ~ F-35042 ~ R e n n e s, ~ F r a n c e ~}$ \\ ${ }^{\mathrm{b}}$ Bioprox, 6 rue Barbès, 92532 Levallois-Perret, France \\ ${ }^{\mathrm{c}}$ Université de Rennes I, Univ. Rennes, Rennes, France \\ ${ }^{\mathrm{d}}$ Bba, Pôle Agronomique Ouest, Régions Bretagne et Pays de la Loire, F-35042 Rennes, France \\ e de Duve Institute, Université catholique de Louvain, Avenue Hippocrate 75, Brussels 1200, Belgium \\ ${ }^{\mathrm{f}}$ Univ. Rennes, CNRS, ISCR, - UMR 6226, PRISM, BIOSIT - UMS 3480, F-35000 Rennes, France
}

A R T I C L E IN F O

\section{Keywords:}

Osmoadaptation

Propionibacteria

Stress tolerance

Proteomics

Probiotic

Freeze-drying

\begin{abstract}
A B S T R A C T
Propionibacterium freudenreichii is a beneficial bacterium used as a cheese starter and as a probiotic. Indeed, selected strains of $P$. freudenreichii combine both technological and health-promoting abilities. Moreover, during large-scale industrial production of dried bacteria and during consumption, $P$. freudenreichii may undergo different stressful processes. Osmotic adaptation was shown to enhance $P$. freudenreichii tolerance towards stresses, which are encountered during freeze-drying and during digestion. In this report, we compared the osmoadaptation molecular mechanisms of two $P$. freudenreichii strains. Both osmotolerance and osmoadaptation were strain-dependent and had different effects on multiple stress tolerance, depending on the presence of osmoprotectants. Availability of glycine betaine (GB) restored the growth of one of the two strains. In this strain, osmotic preadaptation enhanced heat, oxidative and acid stresses tolerance, as well as survival upon freezedrying. However, addition of GB in the medium had deleterious effects on stress tolerance, while restoring optimal growth under hyperosmotic constraint. In the other strain, neither salt nor GB enhanced stress tolerance, which was constitutively low. Accordingly, whole cell proteomics revealed that mechanisms triggered by salt in the presence and in the absence of GB are different between strains. Osmotic adjustment may thus have deleterious effects on industrial abilities of $P$. freudenreichii.

Biological significance: Propionibacteria are found in various niches including fodder, silage, rumen, milk and cheeses. This means adaptation towards different ecological environments with different physicochemical parameters. Propionibacterium freudenreichii, in particular, is furthermore used both as dairy starter and as probiotic and is thus submitted to high scale industrial production. Production and subsequent stabilization still need optimization. Drying processes like freeze-drying are stressful. Osmotic adjustments may modulated tolerance towards drying. However, they are strain-dependent, medium-dependent and may either reduce or increase stress tolerance. A case-by-case study, for each strain-medium thus seems necessary. In this work, we identify key proteins involved in osmoadaptation and give new insights into adaptation mechanisms in $P$. freudenreichii. This opens new perspectives for the selections of strains and for the choice of the growth medium composition.
\end{abstract}

\section{Introduction}

Propionibacterium freudenreichii belongs to the Actinomycetales order, and possesses the GRAS (Generally Recognized As Safe, USA, FDA) and QPS (Qualified Presumption of Safety, EFSA, European
Union) status $[1,2]$. P. freudenreichii is consumed in high amounts, mainly in Swiss-type cheeses, but also in functional probiotic food supplements. Probiotics are "live microorganisms that, when administered in adequate amounts, confer a health benefit on the host" [3]. Modification of the life style, including Western diet (which is high in

\footnotetext{
* Corresponding author.

E-mail address: gwenael.jan@inra.fr (G. Jan).
} 
fat and protein and low in fruits and vegetables), leads to increased incidence of inflammatory bowel disease (IBD), of irritable bowel syndrome (IBS) and of antibiotic-associated diarrhea (AAD), in developed countries. This constitutes a public health concern [4,5]. Probiotics in fermented functional foods, in tablets or in capsules, may reduce ailments linked to some of these troubles, in conjunction with usual treatments [6].

$P$. freudenreichii is a promising probiotic bacterium. Indeed, its consumption leads to increased intestinal bifidobacteria population in human volunteers $[7,8]$. Several $P$. freudenreichii potent beneficial effects were reported, including the anti-inflammatory modulation of the gut mucosa in the context of inflammation [1,9]. Selected strains of $P$. freudenreichii indeed modulate gut inflammation via the induction of the immunomodulatory cytokine IL-10, which is mediated by S-layer proteins [10,11]. Efficacy of probiotics depend on the amount of live probiotic bacteria within a preparation, which often has to be optimized [12]. It also depends on probiotic bacteria survival during the digestion [2]. The international Dairy Federation (IDF) recommends a minimum of $10^{7}$ live probiotic bacterial cells per gram or milliliter of product at the time of consumption [13]. To produce tablets or capsules, the drying process and the probiotic product formulation require optimization, in order to keep alive the maximum of probiotic bacteria per gram during drying and storage. Two drying processes can be used to stabilize bacteria: freeze-drying and spray-drying. The freeze-drying process is a well-known process, the most used, and it allows drying of bacteria with a high viability [14]. However, spray-drying requires less energy, with a higher productivity, compared to freeze-drying, thus offering a promising alternative [15-17]. These two processes are stressful, freeze-drying imposing osmotic and cold stresses, whereas spray-drying imposes thermal, osmotic and oxidative stresses [18]. Ingested probiotic bacteria are submitted to the digestion process and should reach the colon alive, thus surviving acidic conditions of the stomach and presence of enzymes and bile salts in the intestine [19]. Furthermore, osmolality within the gastrointestinal tract is constantly changing as a result of water absorption [20].

Depending on bacterial species and strains, stress adaptation may lead to increased viability during drying [17,21-24], acid stress $[25,26]$, and bile salts stress $[27,28]$, thanks to cross protection. During osmotic stress, general stress proteins are overproduced [20,28,29]. Chaperones and proteases limit the impact of deleterious aggregation of denatured proteins [30]. During osmoadaptation, bacteria accumulate compatibles solutes [31], which can be imported inside the cell, or synthesized de novo. Compatibles solutes may preserve turgescent pressure and enable cell growth and division [32]. Bacteria like $L$. plantarum can accumulate glutamate during osmoadaptation [33,34]. Some authors reported that $P$. freudenreichii is able to accumulate trehalose and glycine betaine (GB) under osmotic constraint [16,35]. During osmoadaptation, $P$. freudenreichii can accumulate energy storage molecules like glycogen and polyphosphate, in a very rich growth medium [29]. This specific growth conditions seemed promising in the aim to produce more resistant probiotic, as they enhanced $P$. freudenreichii resistance to acid, to bile salts stress and to spray-drying $[16,36]$. Osmoadaptation depending on both the strain and the culture medium, a screening is required to optimize probiotic products and to understand the effects of growth conditions. In this report, we investigated benefits and drawbacks of osmotic adjustment in two different strains of $P$. freudenreichii.

\section{Materials and methods}

\subsection{Strains and pre-culture}

Propionibacterium freudenreichii CIRM-BIA 129 (equivalent ITG P20) and CIRM-BIA 1025 (equivalent ITG P1) were provided, stored and maintained by the CIRM-BIA Biological Resource Center (Centre International de Ressources Microbiennes-Bactéries d'Intérêt
Table 1

Composition of the MMO (Medium Minus Osmoprotectants).

\begin{tabular}{|c|c|}
\hline Constituent & Final concentration \\
\hline Sodium lactate & $12.8 \mathrm{~g} / \mathrm{L}$ \\
\hline $\mathrm{KH}_{2} \mathrm{PO}_{4}$ & $0.6 \mathrm{~g} / \mathrm{L}$ \\
\hline Potassium acetate & $0.4 \mathrm{~g} / \mathrm{L}$ \\
\hline $\mathrm{MgSO}_{4} \cdot 7 \mathrm{H}_{2} \mathrm{O}$ & $50 \mathrm{mg} / \mathrm{L}$ \\
\hline $\mathrm{MnSO}_{4} \cdot 4 \mathrm{H}_{2} \mathrm{O}$ & $5 \mathrm{mg} / \mathrm{L}$ \\
\hline $\mathrm{FeSO}_{4} \cdot 7 \mathrm{H}_{2} \mathrm{O}$ & $2.5 \mathrm{mg} / \mathrm{L}$ \\
\hline $\mathrm{CuSO}_{4}$ & $2.5 \mathrm{mg} / \mathrm{L}$ \\
\hline Cobalt acetate & $0.25 \mathrm{mg} / \mathrm{L}$ \\
\hline $\mathrm{ZnSO}_{4}$ & $15 \mu \mathrm{g} / \mathrm{L}$ \\
\hline $\mathrm{H}_{3} \mathrm{BO}_{3}$ & $1 \mu \mathrm{g} / \mathrm{L}$ \\
\hline $\mathrm{Na}_{2} \mathrm{MoO}_{4}$ & $1 \mu \mathrm{g} / \mathrm{L}$ \\
\hline Thiamine & $50 \mu \mathrm{g} / \mathrm{L}$ \\
\hline Pyridoxal & $100 \mu \mathrm{g} / \mathrm{L}$ \\
\hline Calcium pantothenate & $50 \mu \mathrm{g} / \mathrm{L}$ \\
\hline Riboflavine & $50 \mu \mathrm{g} / \mathrm{L}$ \\
\hline Nicotinamide & $100 \mu \mathrm{g} / \mathrm{L}$ \\
\hline p-Aminobenzoic acid & $10 \mu \mathrm{g} / \mathrm{L}$ \\
\hline Biotine & $4 \mu \mathrm{g} / \mathrm{L}$ \\
\hline Folic acid & $20 \mu \mathrm{g} / \mathrm{L}$ \\
\hline Cyanocobalamine & $2 \mu \mathrm{g} / \mathrm{L}$ \\
\hline L-Ala & $50 \mathrm{mg} / \mathrm{L}$ \\
\hline L-Arg & $160 \mathrm{mg} / \mathrm{L}$ \\
\hline L-Asn & $150 \mathrm{mg} / \mathrm{L}$ \\
\hline L-Asp & $250 \mathrm{mg} / \mathrm{L}$ \\
\hline L-Cys & $140 \mathrm{mg} / \mathrm{L}$ \\
\hline Gly & $80 \mathrm{mg} / \mathrm{L}$ \\
\hline L-His & $100 \mathrm{mg} / \mathrm{L}$ \\
\hline L-Ile & $180 \mathrm{mg} / \mathrm{L}$ \\
\hline L-Leu & $300 \mathrm{mg} / \mathrm{L}$ \\
\hline L-Lys & $220 \mathrm{mg} / \mathrm{L}$ \\
\hline DL-Met & $60 \mathrm{mg} / \mathrm{L}$ \\
\hline L-Phe & $170 \mathrm{mg} / \mathrm{L}$ \\
\hline L-Ser & $180 \mathrm{mg} / \mathrm{L}$ \\
\hline L-Thr & $150 \mathrm{mg} / \mathrm{L}$ \\
\hline L-Trp & $50 \mathrm{mg} / \mathrm{L}$ \\
\hline L-Tyr & $60 \mathrm{mg} / \mathrm{L}$ \\
\hline DL-Val & $480 \mathrm{mg} / \mathrm{L}$ \\
\hline Adenine & $5 \mathrm{mg} / \mathrm{L}$ \\
\hline Guanine & $5 \mathrm{mg} / \mathrm{L}$ \\
\hline Uracile & $5 \mathrm{mg} / \mathrm{L}$ \\
\hline Xanthine & $5 \mathrm{mg} / \mathrm{L}$ \\
\hline
\end{tabular}

Alimentaire, INRA, Rennes, France). The strains are routinely cultivated in yeast extract lactate (YEL) medium [37] in this study, they are also cultivated in MMO (Medium Minus Osmoprotectants). MMO is a synthetic medium which was derivated from CdM describe previously [12], MMO medium has the same composition as CdM but glutamate, glutamine and proline, which are considered as potent sources of osmoprotectants, were removed. $P$. freudenreichii was grown at $30{ }^{\circ} \mathrm{C}$ without agitation under microphilic condition. Composition of MMO is detailed in Table 1.

\subsection{Bacterial growth under osmotic stress}

P. freudenreichii CIRM-BIA 129 and CIRM-BIA 1025 were grown under different condition: in YEL medium ( 0.429 osmol), in YEL medium with $0.9 \mathrm{M} \mathrm{NaCl}$ (YEL $+\mathrm{NaCl}, 1.958 \mathrm{osmol}$ ) and in MMO, MMO with salt $0.4 \mathrm{M}$ (MMO $+\mathrm{NaCl}, 0.958 \mathrm{osmol})$ and $\mathrm{MMO}$ with $0.9 \mathrm{M} \mathrm{NaCl}$ and $1 \mathrm{mM}$ of $\mathrm{GB}$ (MMO $+\mathrm{NaCl}+\mathrm{GB} 0.960$ osmol). $0.4 \mathrm{M}$ $\mathrm{NaCl}$ is the highest salt concentration allowing $P$. freudenreichii growth in $\mathrm{MMO}$ medium. $0.9 \mathrm{M} \mathrm{NaCl}$ is the highest salt concentration allowing $P$. freudenreichii growth in YEL medium. The GB concentration used in the chemically defined MMO medium was $1 \mathrm{mM}$, reported as the optimal concentration in previous reports including the actinobacteria Brevibacterium ammoniagenes [38] and Propionibacterium freudenreichii [39]. Bacterial populations were followed by Optical Density (OD) at $650 \mathrm{~nm}$. 


\subsection{Stress challenges}

Heat, oxidative, bile salts and acid challenge were applied to cultures at the beginning of stationary-phase (when maximal OD was reached). Heat challenge was performed by placing $2 \mathrm{~mL}$ (in a $15 \mathrm{~mL}$ Falcon tube) of $P$. freudenreichii culture in a water bath at $60^{\circ} \mathrm{C}$ for $10 \mathrm{~min}$ [28]. Oxidative challenge was applied by adding $1.25 \mathrm{mM}$ of hydrogen peroxide (Labogros, France) to $2 \mathrm{~mL}$ of $P$. freudenreichii culture during $1 \mathrm{~h}$ at $30^{\circ} \mathrm{C}$ [40]. Acid challenge was applied by re-suspending $P$. freudenreichii in MMO medium adjusted to $\mathrm{pH} 2.0$ by using $\mathrm{HCl}$ at $30^{\circ} \mathrm{C}$ followed by a $1 \mathrm{~h}$ incubation [36]. Bile salts challenge was performed by adding $1 \mathrm{~g} \cdot \mathrm{L}^{-1}$ of a bile salts mixture (an equimolar mixture of cholate and deoxycholate; Sigma Chemical, St. Louis, MO, USA) in the culture during $1 \mathrm{~h}$ at $37^{\circ} \mathrm{C}$ [27]. CFU counting was performed after challenge. In order to calculated survival percentage, a CFU counting was made, with untreated culture left for the same time at $30^{\circ} \mathrm{C}$ as a control.

\subsection{Identification and quantification of osmoprotectants accumulated by $P$. freudenreichii CIRM-BIA 129}

\subsubsection{Extraction of accumulated osmoprotectants}

P. freudenreichii CIRM-BIA 129 was grown in MMO, MMO $+\mathrm{NaCl}$ and $\mathrm{MMO}+\mathrm{NaCl}+\mathrm{GB}$. During exponential phase $(\mathrm{OD}=0.8)$, cells were harvested by centrifugation $(8000 \mathrm{~g}, 10 \mathrm{~min})$. Cells were washed twice in a $\mathrm{NaCl}$ solution with the same osmolality than the culture medium. Cells were then re-suspended in $2 \mathrm{~mL}$ of distilled water, then $8 \mathrm{~mL}$ of absolute ethanol were added. The suspension was homogenized and centrifuged $(8000 \mathrm{~g}, 10 \mathrm{~min})$ in order to remove cell fragments. The supernatant extract was evaporated during $7 \mathrm{~h}$ with a rotary evaporator. Dried extracts were then solubilized in deuterium oxide (Sigma-Aldrich, USA).

\subsubsection{NMR (Nuclear Magnetic Resonance) analyses}

All ${ }^{1} \mathrm{H}$ and ${ }^{13} \mathrm{C}$ NMR spectra were recorded at $298 \mathrm{~K}$ on a Bruker Avance 500 spectrometer equipped with a $5 \mathrm{~mm}$ TCI triple-resonance cryoprobe (PRISM core facility, Rennes). ${ }^{1} \mathrm{H}$ spectra were acquired with a $6 \mathrm{kHz}$ spectral width, $32 \mathrm{~K}$ data points and a total repetition time of $6.73 \mathrm{~s} .{ }^{13} \mathrm{C}$ spectra were acquired using a proton power-gated decoupling sequence with a $30^{\circ}$ flip angle, a $30 \mathrm{kHz}$ spectral width, $64 \mathrm{~K}$ data points and a total repetition time of $3.08 \mathrm{~s}$. The data were processed with Topspin software (Bruker Biospin). Before applying the Fourier transform, free induction decays of ${ }^{1} \mathrm{H}$ spectra were treated with an exponential broadening of $0.3 \mathrm{~Hz}$.

Samples were solubilized in $\mathrm{D}_{2} \mathrm{O}$. 3-(Trimethylsilyl)propionic2,2,3,3-d4 acid sodium salt (TSP-d4) (Sigma-Aldrich, USA) served as an internal reference for ${ }^{1} \mathrm{H}$ and ${ }^{13} \mathrm{C}$ chemical shifts.

Relative concentration of trehalose, glutamate and glycine betaine in the samples was determined by integration of their ${ }^{1} \mathrm{H}$ signals. Results are expressed as NMR relative units (RU).

\subsection{Label free proteomics}

\subsubsection{Whole-cell protein extraction and protein tryptic digestion}

The label free proteomics was have been conducted as Huang et al. 2018 [41]. At the beginning of stationary phase, $P$. freudenreichii cells were harvested by centrifugation and washed twice with $\mathrm{PBS}$ buffer $\left(\mathrm{NaCl} \quad 8 \mathrm{~g} \cdot \mathrm{L}^{-1}, \quad \mathrm{KCl} \quad 2 \mathrm{~g} \cdot \mathrm{L}^{-1} \mathrm{KH}_{2} \mathrm{PO}_{4} \quad 2 \mathrm{~g} \cdot \mathrm{L}^{-1}, \mathrm{Na}_{2} \mathrm{HPO}_{4} \quad 12 \mathrm{H}_{2} \mathrm{O}\right.$ $35,8 \mathrm{~g} \cdot \mathrm{L}^{-1}$ ). Cell pellets were then re-suspended in lysis solution (lysis solution: $0.5 \mathrm{~mL}$ pH 7.5, $157 \mathrm{~g}$ Tris- $\mathrm{HCl}, 0.03 \mathrm{~g}$ SDS, $0.3 \mathrm{~g}$ DTT and $9.5 \mathrm{~mL} \mathrm{H}_{2} \mathrm{O}$ ), with $1 \mathrm{mM}$ phenylmethylsulfonyl fluoride (PMSF, SigmaAldrich, USA). The solution was frozen for $1 \mathrm{~h}$, then sonicated ( $2 \mathrm{~min} 30$ HZ), and cells were broken using zirconium beads in the homogenizer (Homogénéisateur Precellys Evolution - Bertin Instruments, France). The resulting SDS extracts were recovered by centrifugation $\left(21,000 \times g ; 20^{\circ} \mathrm{C} ; 20 \mathrm{~min}\right)$ and then cleaned and quantified using the two-dimensional (2-D) clean-up kit (GE Healthcare Bio-Sciences $A B$, Uppsala, Sweden) and the 2-D quant kit (GE Healthcare Bio-Sciences $\mathrm{AB}$, Uppsala, Sweden), respectively. Tryptic digestion was performed on $100 \mu \mathrm{g}$ of whole-cell proteins from each sample during $15 \mathrm{~h}$ at $37^{\circ} \mathrm{C}$ using Sequencing Grade Modified Trypsin (Promega, Madison, USA) according to the manufacturer's instructions and as described previously [41]. Spectrophotometric-grade trifluoroacetic acid (TFA) (Sigma-Aldrich, USA) was added in order to stop the digestion.

\subsubsection{Nano-LC-MS/MS}

Experiments were performed as previously described [41]. Experiments were performed using a nano RSLC Dionex U3000 system fitted to a Q-Exactive mass spectrometer (Thermo Scientific, San Jose, USA) equipped with a nano-electrospray ion source. A preliminary sample concentration step was performed on a C18 pepMap100 reverse phase column (C18 column, 300- $\mu \mathrm{m}$ inner diameter (i.d.), $5 \mathrm{~mm}$ length, $5 \mu \mathrm{m}$ particle size, $100 \AA$ pore size; Dionex, Amsterdam, The Netherlands). Peptides separation was performed on a reversed-phase column (PepMap $100 \mathrm{C} 18,75 \mu \mathrm{m}$ i.d., $250 \mathrm{~mm}$ length, $3 \mu \mathrm{m}$ particle size, $100 \AA$ pore size; Dionex, Amsterdam, The Netherlands) with a column temperature of $35^{\circ} \mathrm{C}$, using solvent A $(2 \%(v / v)$ acetonitrile (Honeywell, USA), $0.08 \%(\mathrm{v} / \mathrm{v})$ formic acid and $0.01 \%(\mathrm{v} / \mathrm{v})$ TFA in deionized water) and solvent B (95\% (v/v) acetonitrile, $0.08 \%(\mathrm{v} / \mathrm{v})$ formic acid and $0.01 \%(\mathrm{v} / \mathrm{v})$ TFA in deionized water). Peptides were separated using a gradient of 5 to $35 \%$ solvent B over 80 min followed by 35 to $85 \%$ solvent B over $5 \mathrm{~min}$ at a flow rate of $0.3 \mu \mathrm{L} / \mathrm{min}$. Eluted peptides were directly electro sprayed into the mass spectrometer operating in positive ion mode with a voltage of $2 \mathrm{kV}$. Spectra were recorded in full MS mode and selected in a mass range $250-2000 \mathrm{~m} / \mathrm{z}$ for MS spectra with a resolution of 70,000 at $\mathrm{m} / \mathrm{z} 200$. For each scan, the ten most intense ions were selected for fragmentation. MS/MS spectra were recorded with a resolution of 17,500 at $\mathrm{m} / \mathrm{z} 200$ and the parent ion was subsequently excluded from MS/MS fragmentation for $20 \mathrm{~s}$. The instrument was externally calibrated according to the supplier's instructions.

\subsubsection{Protein identification}

Proteins identification was performed as previously described [41]. Peptides were identified from the MS/MS spectra using X!Tandem pipeline software (Langella et al., 2017). The search was performed against a database composed of proteomes of strains $P$. freudenreichii CIRM-BIA 129 and CIRM-BIA 1025 (downloaded from NCBI.nlm.nih. gov on the 23rd of August 2018). Database search parameters were specified as follow: trypsin cleavage was used and the peptide mass tolerance was set to $10 \mathrm{ppm}$ for MS and 0.05 Da for MS/MS. Oxidation of methionine and phosphorylation of threonine, serine and tryptophan were selected as a variable modification. For each peptide identified, a minimum score corresponding to an e-value below 0.05 was considered as a prerequisite for peptide validation.

\subsubsection{Protein quantification}

Protein quantification was performed as previously described [41]. Every peptide identified by tandem mass spectrometry was quantified using the free MassChroQ software (Valot et al., 2011) before data treatment and statistical analysis within the R software (R 3.2.2, Project for statistical computing). A specific R package called 'MassChroqR' was used to automatically filter dubious peptides for which standard deviation of retention time was superior to $40 \mathrm{~s}$ and to regroup peptide quantification data into proteins. Two different and complementary methods of analysis were used, based on peak counting or XIC (eXtracted Ion Current). For peak counting analysis, variance analysis was performed on proteins with a minimum peak ratio of 1.5 between both culture conditions. Proteins with an adjusted $p$-value $<.05$ were considered significantly different. For XIC based quantification, normalization was performed to take into account possible global quantitative variations between LC-MS runs. Peptides shared between 
different proteins were automatically excluded from the data set as well as peptides present in $<80 \%$ of samples. Missing data were then imputed from a linear regression based on other peptide intensities for the same protein [42]. Analysis of variance was used to determine proteins with significantly different abundance between our two culture conditions.

\subsection{Freeze-drying}

$P$. freudenreichii strains were grown in the three different growth media. At the beginning of the stationary phase, cultures were harvested $\left(8000 \mathrm{~g}, 10 \mathrm{~min}, 30^{\circ} \mathrm{C}\right)$. Pellets were then homogenized in a maltodextrin solution (100 g.L-1) (Roquette, France). The bacterial solutions were then freeze-dried (2253-04, Serail, France).

\subsection{Statistical analysis}

The data were from triplicate samples. All the results are presented as mean value with standard deviation. Statistical significance was set at $p<.05$. Calculations were performed using GraphPad Prism Software (Prism 7 for Windows).

\section{Results}

\subsection{P. freudenreichii growth in hypertonic media is strain-dependent}

The growth of $P$. freudenreichii CIRM-BIA 129 and 1025 was analyzed in YEL medium containing increasing $\mathrm{NaCl}$ concentrations, or in MMO supplemented or not with $0.4 \mathrm{M} \mathrm{NaCl}$ and $1 \mathrm{mM} \mathrm{GB}$ (Fig. 1). The CIRM-BIA 129 strain was able to grow in the rich YEL medium supplemented by $\mathrm{NaCl}$, up to $0.9 \mathrm{M}$, with a final OD close to the control without $\mathrm{NaCl}$. High salt concentrations reduced significantly the growth rate (Fig. 1A). In the same conditions, the CIRM-BIA 1025 growth in YEL $0.4 \mathrm{M} \mathrm{NaCl}$ was similar to that of CIRM-BIA 129 but was completely inhibited in the presence of $0.9 \mathrm{M}$ of $\mathrm{NaCl}$, indicating that this strain is more susceptible to osmotic stress (Fig. 1B). In the chemically defined MMO medium, the two strains displayed a similar growth profile. With the addition of $0.4 \mathrm{M} \mathrm{NaCl}$, both strains had a limited growth with a reduced finale OD and growth rate (Fig. 1C,D), while no growth occurred for both strains in the presence of $0.9 \mathrm{M} \mathrm{NaCl}$ (data not shown). Addition of GB partially restored growth of $P$. freudenreichii CIRM-BIA 129 in salted MMO. By contrast, growth of CIRM-BIA 1025 was similar despite the presence or not of GB (Fig. 1D).

\subsection{Osmoprotectants accumulation in P. freudenreichii is strain-dependent}

Intracellular accumulation of osmoprotectants was quantified by NMR analysis. P. freudenreichii CIRM-BIA 129 grown in MMO $+0.4 \mathrm{M}$ $\mathrm{NaCl}$ accumulated trehalose (62.3 RU) and glutamate (37.7 RU) (Fig. 2). The strain CIRM-BIA 1025 accumulated the same compounds with nearly the same proportion, $60.9 \%$ and $39.1 \%$, respectively. In the presence of glycine betaine, the CIRM-BIA 129 strain accumulated GB as the bulk majority of intracellular osmoprotectants (89.5 RU), with only limited amounts of glutamate ( $8 \mathrm{RU}$ ) and nearly no trehalose (2.5 RU). In the same conditions, the CIRM-BIA 1025 strain accumulated more diverse compatible solutes, with much less GB (29.4 RU) and a majority of trehalose (46 RU), while glutamate (24.5 RU) was also accumulated. These results suggest that both strains possess GB uptake system. However, the replacement of endogenous osmolytes by GB, classically observed in many bacteria, is only effective for CIRM-BIA 129.

\subsection{Multiple stress tolerance of $P$. freudenreichii is strain- and medium- dependent}

P. freudenreichii viability was monitored by numeration, before and after stress challenges, in order to determine viability. We selected a series of stresses relevant to both technological and digestive processes. CIRM-BIA 129 tolerance towards heat, acid and oxidative lethal challenges was higher, when grown in salted MMO medium, compared to control MMO (Fig. 3A, B, C). This evidences osmotically induced multitolerance. It depends on the stress applied since the addition of $\mathrm{NaCl}$, in the MMO medium, decreased CIRM-BIA 129 tolerance towards a bile salts lethal challenge, compared to control MMO (Fig. 3D). With the addition of GB, the viability of the CIRM-BIA 129 strain decreased for all lethal challenges, compared to $\mathrm{MMO}+\mathrm{NaCl}$ medium. This indicates abrogation of osmotically induced multitolerance, as a result of GB accumulation. By contrast, neither the addition of $\mathrm{NaCl}$, nor that of GB, had any impact on $P$. freudenreichii CIRM-BIA 1025 viability after heat challenge (Fig. 3E). These additions even decreased the viability after oxidative and acid challenges in this strain (Fig. 3F, G, H). Then, the response of 1025 and 129 are clearly different despite the accumulation of osmoprotectants, when submitted to osmotic stress.

\subsection{Modulation of protein expression during osmoadaptation}

To understand the difference observed between these two strains, we realized a proteomic differential analysis. We focused on proteins that were differentially express for at least one condition between $\mathrm{MMO}, \mathrm{MMO}+\mathrm{NaCl}$ and $\mathrm{MMO}+\mathrm{NaCl}+\mathrm{GB}$, for $P$. freudenreichii CIRMBIA 129 or for $P$. freudenreichii CIRM-BIA 1025, with a minimum ratio of 1.5 or $<0.66$. A total of 387 proteins were significantly modulated (See Supplemental Table). Among these, 58 proteins were involved in energy production, conversion or carbohydrate and transport (Table 2), 53 were involved in amino acid metabolism and transport (Table 3) and 35 in post-translational modification, protein turnover, chaperone function (Table 4).

A PCA analysis was performed on the abundances of the 1362 propionibacterial proteins that were detected in this proteomic investigation (Fig. 4A). It revealed that $P$. freudenreichii CIRM-BIA 129 displayed three different profiles, according to the culture conditions. By contrast, CIRM-BIA 1025 only displayed two different profiles: one for the MMO medium, while the second profile was the same for the $\mathrm{MMO}+\mathrm{NaCl}$ and for the $\mathrm{MMO}+\mathrm{NaCl}+\mathrm{GB}$ culture media (Fig. 4A). Salt addition strongly affected cellular proteome in both strains. Indeed, Fig. 4A clearly shows a shift of the global proteome towards increased values of the Axis 1, yet reduced values of the Axis 2, whatever the strain. However, glycine betaine addition further changed $P$. freudenreichii CIRM-BIA 129 global proteome by partially restoring the initial value of Axis 1 . By contrast, glycine betaine addition add little or no effect on CIRM-BIA 1025 global proteome. This is consistent with the absence of effect of GB on CIRM-BIA 1025 growth. The corresponding heatmap (Fig. 4B) further evidences three very different proteomes in the CIRM-BIA 129 strain, while only two proteomic patterns $(\mathrm{MMO}+\mathrm{NaCl}$ and $\mathrm{MMO}+\mathrm{NaCl}+\mathrm{GB})$ are very close concerning the CIRM-BIA 1025 strain. We then selected 321 differential proteins exhibiting ratios below 0.66 or above 1.5 . The corresponding Venn diagram, shown in Fig. 4C, further indicates strain-dependent proteomic readjustments. Among the 321 regulated proteins, only 60 were regulated in both strains. By contrast, 134 proteins were exclusively regulated in CIRM-BIA 129 and 127 exclusively in CIRM-BIA 1025. In CIRMBIA 129, a high number of stress proteins was detected in the presence of salt without GB. By contrast, in CIRM-BIA 1025, a high number of stress proteomics were observed, whatever the presence or absence of GB.

When looking deeper into the expression of specific proteins, crucial differences, between strains, were evidenced, such as the induction of osmoprotectant uptake OpuA in CIRM-BIA 129, yet not in CIRM-BIA 1025 , as a result of salt addition. This confirmed different behaviors of these strain. Furthermore, looking at proteins involved in energy production and conversion or carbohydrate and transport (Table 2), many adjustments were observed in $P$. freudenreichii CIRM-BIA 129, yet not in 


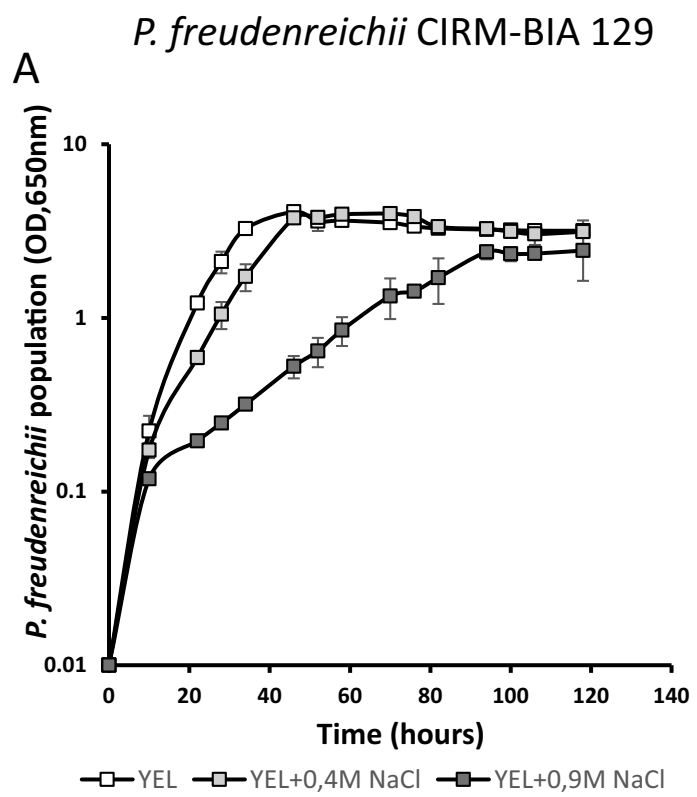

C

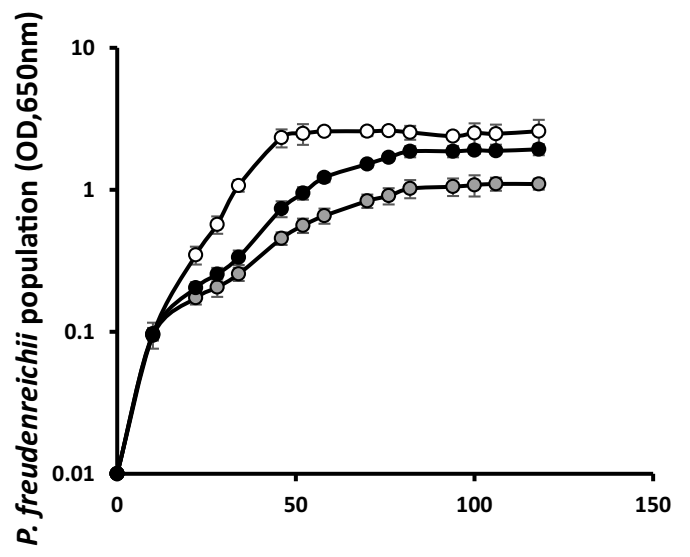

Time (hours)

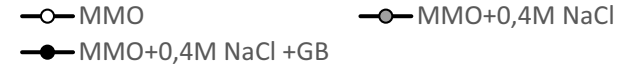

\section{P. freudenreichii CIRM-BIA 1025}

B

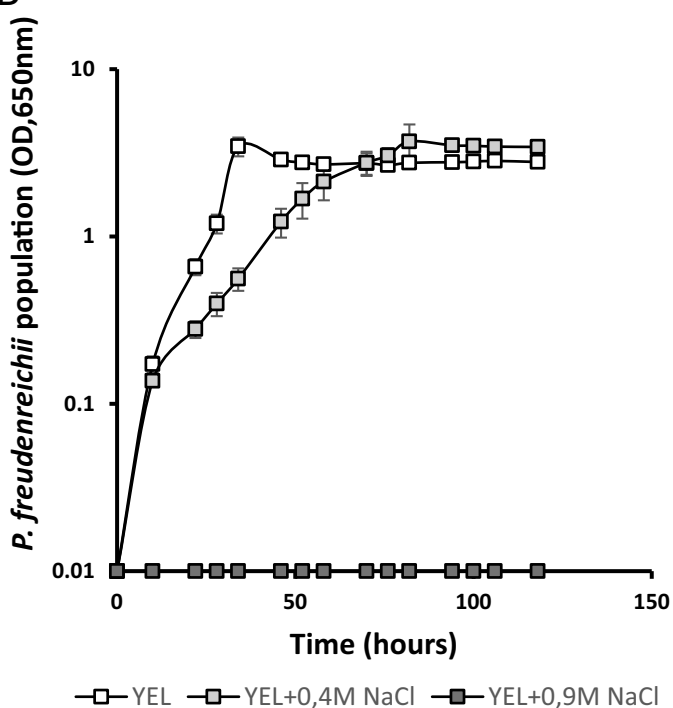

D

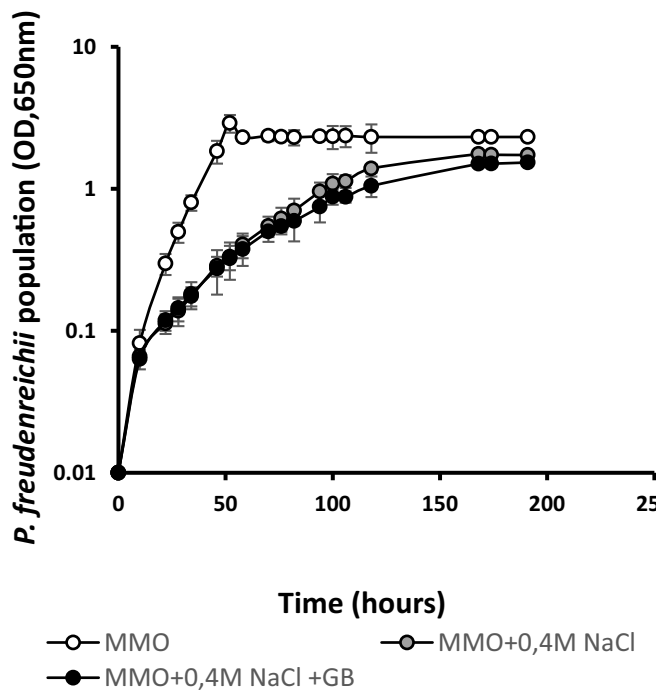

Fig. 1. $P$. freudenreichii growth in the presence of salt is strain-dependent.

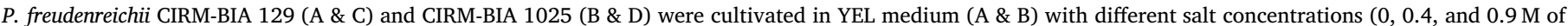
$\mathrm{NaCl})$ or in chemically-defined MMO medium, with or without salt $(0.4 \mathrm{M} \mathrm{NaCl})$, and with or without $1 \mathrm{mM}$ glycine betaine $(\mathrm{C} \& \mathrm{D})$.

the strain CIRM-BIA 1025. As an example, proteins involved in ATP synthesis (ATP synthase F1 sector, ATP synthase delta and B chain), in electron transfer chain (electron transfer flavoprotein, cytochrome d'ubiquinol oxidase, oxidoreductase), and in carbohydrate utilization (enolase, galactokinase, beta-galoctosidase), were modulated by $\mathrm{NaCl}$ addition, and restored by GB addition in the CIRM-BIA 129 strain, yet not in CIRM-BIA 1025 strain. By contrast, some modulations were specific of the strain CIRM-BIA 1025, such as the repression of propionic fermentation enzyme (methylmalonyl-CoA carboxytransferase $5 S$ subutnit) or induction of proteins involved in oxidative stress remediation (nitroreductase, aldo-keto reductase). About proteins involved in amino acid metabolism and transport (Table 3), transporters of osmoprotectants and/or of aminoacids were induced in the presence of $\mathrm{NaCl}$, yet not in the presence of $\mathrm{NaCl}+\mathrm{GB}$, including betaine/carnitine/choline $\mathrm{ABC}$ transporter ATP-binding protein opuCA of glycine and betaine/carnitine/choline $\mathrm{ABC}$ transporter, while one involved in polar aminoacids (polar amino acid $\mathrm{ABC}$ transporter, binding protein component) was repressed, in CIRM-BIA 129. These modulations did not occur in $P$. freudenreichii CIRM-BIA 1025. Proteins involved in osmoprotectants neosynthesis were also regulated in $P$. freudenreichii CIRM-BIA 129 (glutamine synthetase, glutamate deshydrogenase, glutamate synthase large subunit), yet not in 1025. In 1025, by contrast, proteins involved in signal transduction and regulation (nitrogen regulatory protein P II and bifunctional PLP-dependent enzyme with beta cystathionase and maltose regulon repressor activities) were specifically induced.

Concerning proteins involved in post translational modification, protein turnover, chaperone function (Table 4), general stress adaptation proteins were specifically modulated in CIRM-BIA 129, i.e. induced in the presence of $\mathrm{NaCl}$, yet not in the presence of $\mathrm{NaCl}+\mathrm{GB}$, including groES protein 2 and thiol peroxidase. Addition of GB further repressed groEL protein 1 , groEL protein 2 , which also participate in general stress response. A different set of stress proteins were specifically induced in CIRM-BIA 1025, including heat shock protein, groES protein 1 
A

P. freudenreichii CIM-BIA 129

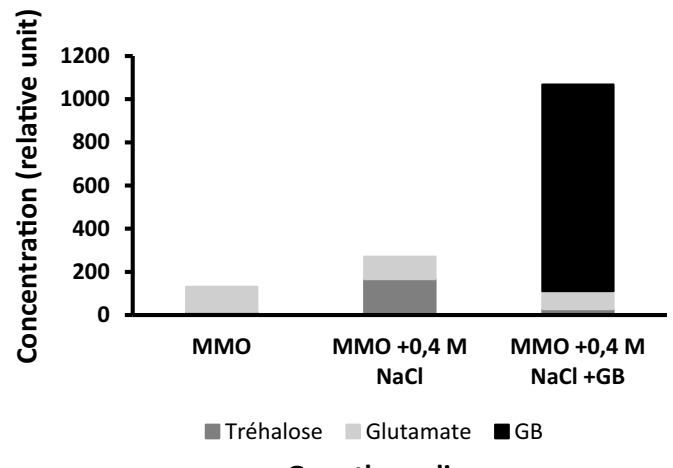

Growth medium
B

\section{P. freudenreichii CIM-BIA 1025}

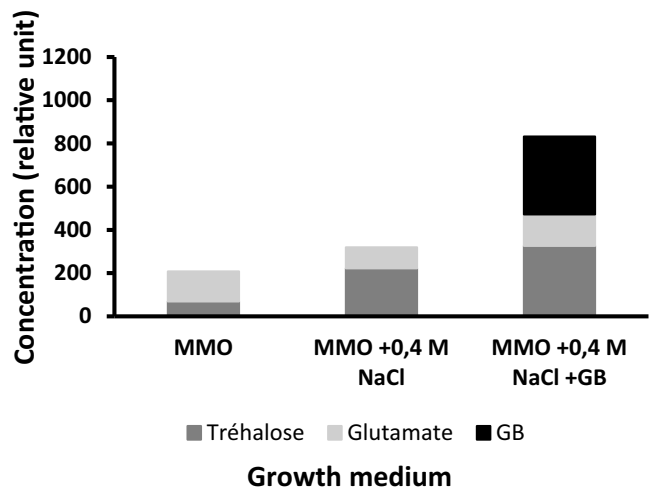

Fig. 2. P. freudenreichii compatibles solutes accumulation is strain and medium-dependent.

P. freudenreichii CIRM-BIA 129 (A) and CIRM-BIA 1025 (B) were cultivated in the different growth media described in Section 2.2. Cytoplasmic extract were made. Osmoprotectants were identified and quantified by NMR analysis in theses extracts. Osmoprotectant accumulation are expressed as relative concentrations.

and chaperone protein Hsp20. Moreover, ATP-dependent protease Clp2, which is involved in misfolded proteins turnover, was induced by salt in both strains, but repressed by the addition of GB only in $P$. freudenreichii CIRM-BIA 129.

\subsection{P. freudenreichii viability after freeze-drying}

P. freudenreichii CIRM-BIA 129, when cultivated in MMO medium, displayed a low viability upon freeze-drying (3.3\%) (Fig. 5). As previously shown for individual stress challenge (Fig. 3), viability was enhanced as a result of salt addition to this medium (9.4\%). However, such improvement was reduced by the addition of GB, and the viability of $P$. freudenreichii CIRM-BIA 129 decreased to $6.8 \%$. By contrast, the CIRM-BIA 1025 strain exhibited its best viability when cultivated in MMO medium (6.5\%). With the addition of salt with or without GB, the P. freudenreichii CIRM-BIA 1025 viability decrease to $4 \%$.

\section{Discussion}

4.1. Osmotic tolerance and adaptation is strain-dependent in $P$. freudenreichii

P. freudenreichii CIRM-BIA 129 and CIRM-BIA 1025 strains are both able to growth in the rich YEL medium with a low concentration of salt $(0.4 \mathrm{M} \mathrm{NaCl})$. The addition of a high concentration of salt $(0.9 \mathrm{M} \mathrm{NaCl})$ is more selective and allows growth of CIRM-BIA 129, yet not of CIRMBIA 1025. This suggests that the rich YEL medium contains compatible solutes, which CIRM-BIA 129 would better use than CIRM-BIA 1025 does. The restoration of $P$. freudenreichii CIRM-BIA 129 growth in $\mathrm{MMO}+\mathrm{NaCl}$, as a result of GB addition, indicates a key role of $\mathrm{GB}$ in its osmoadaptation. By contrast, GB did not restore CIRM-BIA 1025 growth in $\mathrm{MMO}+\mathrm{NaCl}$. This suggested that $\mathrm{GB}$ is imported and accumulated by CIRM-BIA 129, yet not by CIRM-BIA 1025 . This hypothesis was then shown to be false, as NMR evidenced accumulation of GB in both strains. However, GB levels were much lower in CIRM-BIA 1025 than in CIRM-BIA 129. This small accumulation had no positive impact on CIRM-BIA 1025 growth, in contrast with CIRM-BIA 129. Both strains accumulated glutamate, trehalose and glycine betaine. Glutamate accumulation in hyperosmotic conditions was already reported for Lactobacillus plantarum [32,33]. Trehalose is a key protectant molecule in $P$. freudenreichii, it can be accumulated during acid, cold, osmotic and oxidative treatments $[29,35,43,44]$. GB accumulation has already been observed during $P$. freudenreichii growth in hyper-concentrated rich media [28], but its beneficial effect is shown here to be strain-dependent.

4.2. Benefits and drawbacks of osmoadaptation on cross-protection towards other stress are strain-dependent

$\mathrm{NaCl}$ adaptation enhanced $P$. freudenreichii CIRM-BIA 129 tolerance towards heat, oxidative and acid challenges, as well as towards freezedrying. Restoration by GB in these hyperosmotic conditions however suppressed this cross-protection and even triggered hypersensitivity towards oxidative, bile salts, acid and freeze-drying challenges. Since GB replaces trehalose and glutamate accumulation inside the cells, we can suggest that these molecules could play a major role in cross protection [45]. By contrast, addition of salt failed to provide cross protection in P. freudenreichii CIRM-BIA 1025, and so did the addition of GB. Finally, osmoadaptation had a negative impact on tolerance of both strains towards freeze-drying (Fig. 5).

\subsection{Proteomic patterns may explain differential adaptation and stress tolerance}

Osmoadaptation triggered major modulations of cellular proteins' expression. Indeed, growth under hyperosmotic constraint and in the absence of osmoprotectant induced expression of many proteins involved in stress adaptation (ie osmoprotectant uptake systems) or reflecting metabolic readjustments. The heatmap in Fig. 4B and Venn diagram in Fig. 4C clearly evidence differences in terms of proteomics variations, among strains. Among the 321 stress proteins identified, only 23 were induced whatever the strain and medium. Such a discrepancy highlights the strain-dependence of osmoadaptation. Major proteome changes induced by stress in CIRM-BIA may explain the efficiency of osmoadaptation in this strain. This strain, which was shown to adapt hyperosmotic constraint and to transport GB, overexpressed proteins involved in carbohydrates transport and utilization, electron transfer chain and ATP synthesis (Table 2). Enolase, as an example, was previously shown to participate in multiple stress adaptation in $P$. freudenreichii [27] and in other food-grade bacteria [46]. This glycolytic enzyme is also a component of RNA degradosome, which is involved in RNA processing and gene regulation, in accordance with its role in stress tolerance acquisition in many bacteria [47]. Overexpression of ATPase subunits, allowing enhanced energy production, is a key parameter of adaptation, of intracellular homeostasis and of metabolic readjustments. It was already reported to be involved in acid adaptation 
P. freudenreichii CIRM-BIA 129

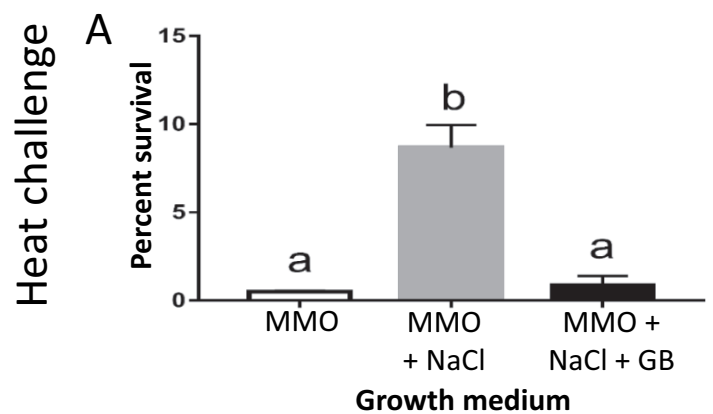

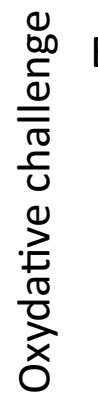

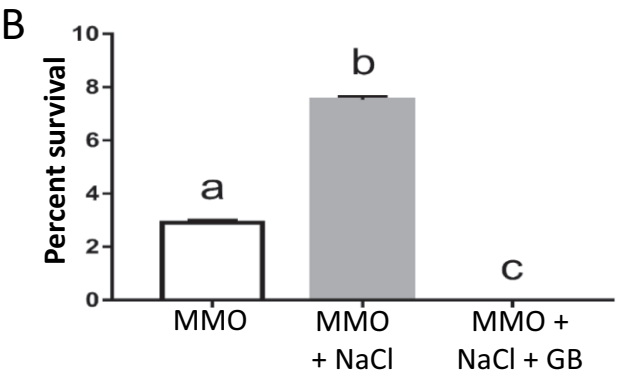

Growth medium

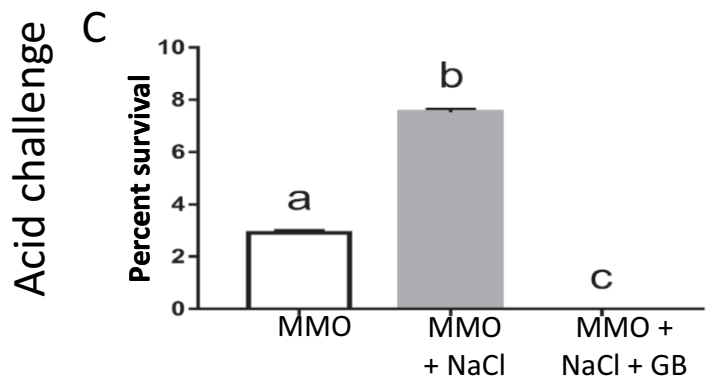

Growth medium

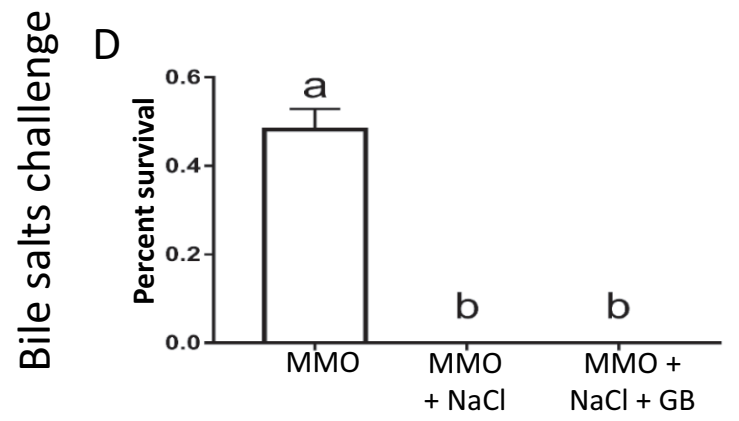

Growth medium
P. freudenreichii CIRM-BIA 1025

E

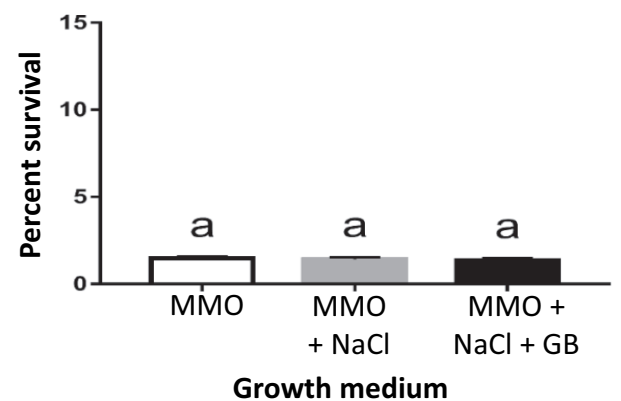

$\mathrm{F}$

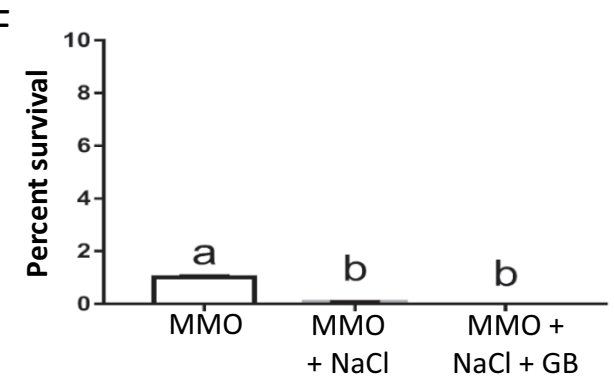

Growth medium

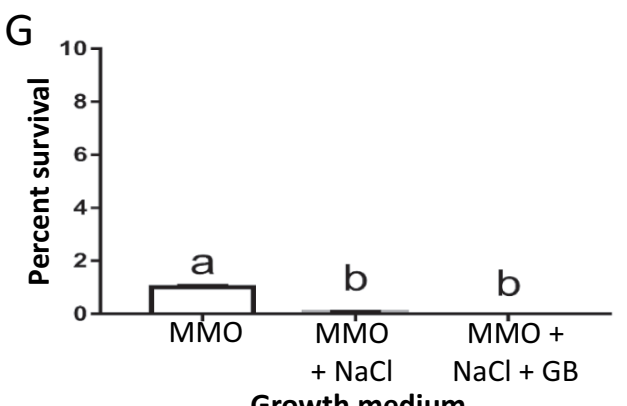

$\mathrm{H}$

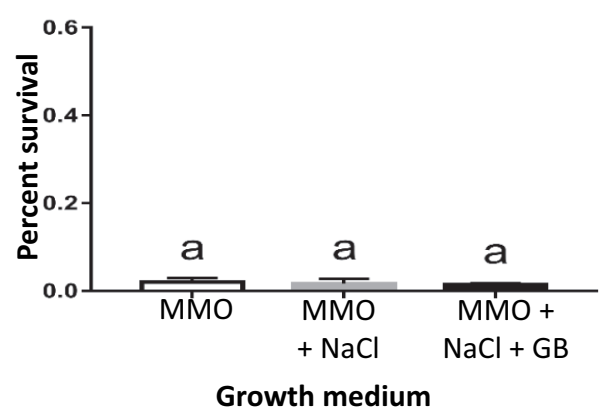

Fig. 3. Cross-protections conferred to $P$. freudenreichii are strain-dependent.

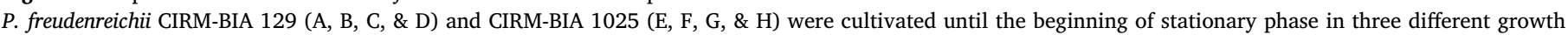

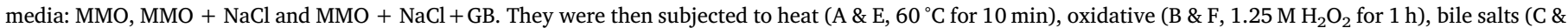

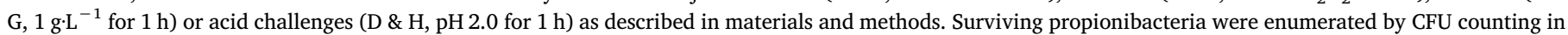

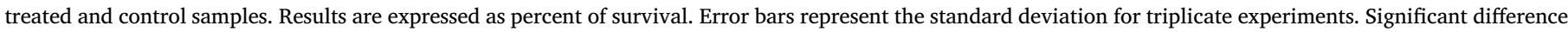
are reported with different letters above the columns $(p>.05)$. 


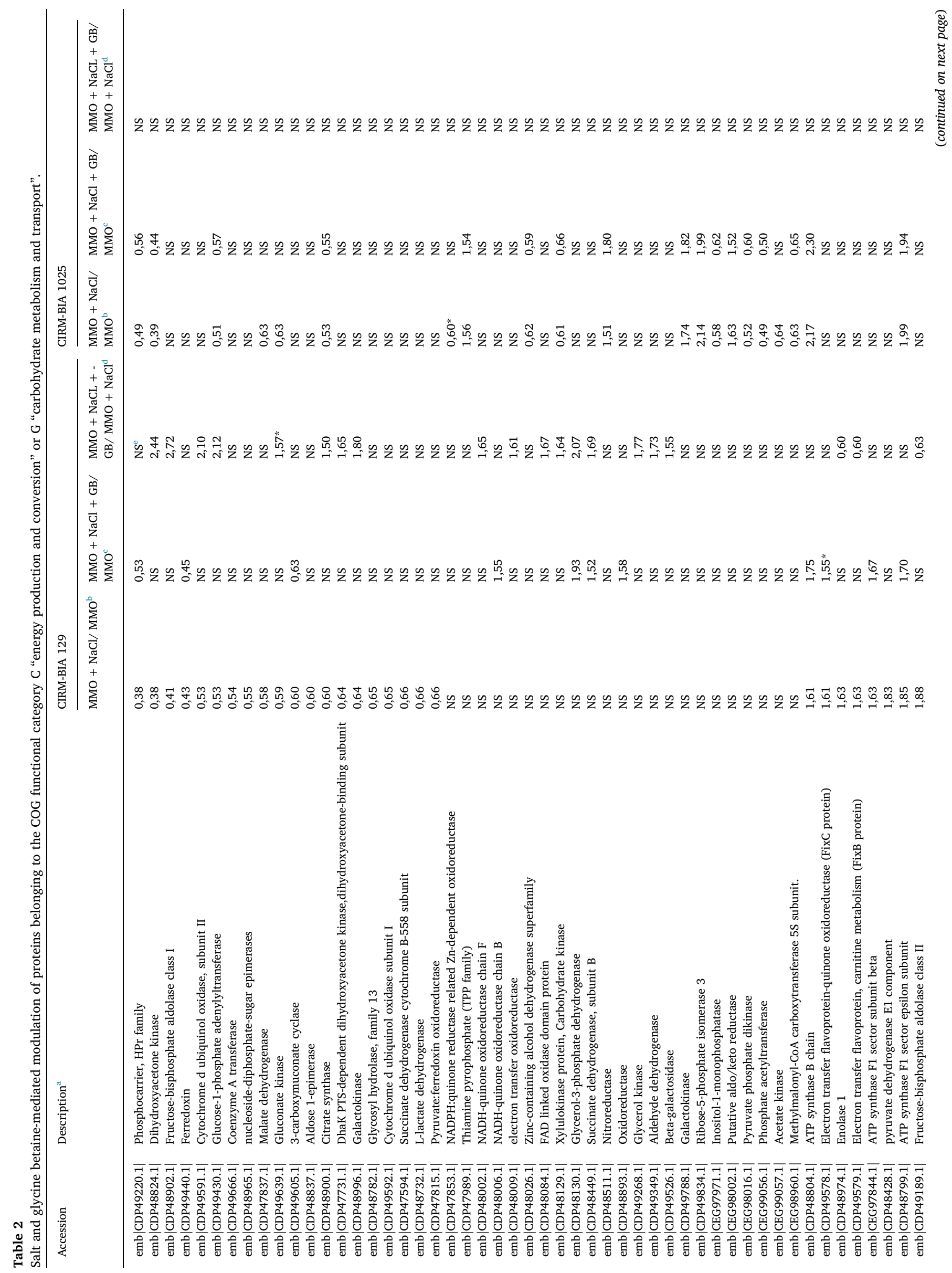




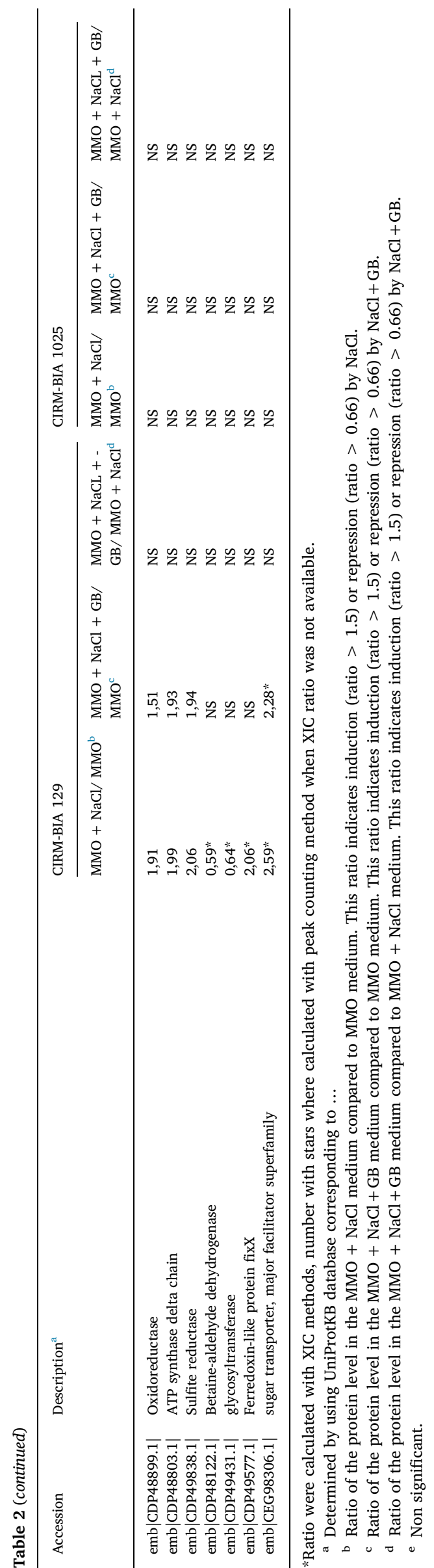

in $P$. acidipropionici [48]. As another key difference between the two strains, CIRM-BIA 129 was able to import GB thanks to the ATP binding protein opuCA of the glycine betaine/carnitine /choline ABC transporter, which were induced here by salt (Table 3). This strain was already reported to overexpress opuCA in hyper concentrated sweet whey [28]. This induction explains the high GB accumulation in $\mathrm{MMO}+\mathrm{NaCl}+\mathrm{GB}$ (Fig. 2) and the restoration of growth (Fig. 1). Furthermore, CIRM-BIA 129 also overexpressed the binding protein of an $A B C$ choline transporter, suggesting the ability to accumulate other osmoprotectants, when provided in the growth medium (Table 3). Salt further triggered over-expression of the GroES chaperone and of proteins involved in oxidative stress remediation (Table 4). By contrast, enzymes such as glutamine synthetase and glutamate dehydrogenase, which are susceptible to reduce intracellular compatible solute concentration, were repressed (Table 3). Finally, the overexpression of several proteins involved in stress adaptation is consistent with the enhanced tolerance towards stresses (Fig. 3) and towards freeze-drying (Fig. 5).

\subsection{Glycine betaine modulates both stress proteome and resistance}

P. freudenreichii CIRM-BIA 129 over-produced osmoprotectants transporters in $\mathrm{MMO}+\mathrm{NaCl}$. This over-production was however no more significant when GB was added, while GB restored growth (Table 3). Indeed, the absence of potent osmoprotectant in $\mathrm{MMO}+\mathrm{NaCl}$ triggers the need for increased activity of such transporters. In many bacteria, such transporters are induced by the hyperosmotic constraint [49-51]. By contrast, once turgor pressure and growth are restored by GB, opuA expression is downregulated in response to the increase in the intracellular GB pool [49]. The "normalization" of the expression of many stress proteins, as a result of growth restoration by the availability of GB, is consistent with the loss of crossprotection towards stresses (Fig. 3) and towards freeze-drying (Fig. 5). Similarly, GB import limits Salmonella stress resistance, while salt adaptation without GB import leads to trehalose accumulation and to enhanced resistance in this bacterium [52]. Interestingly, the regulation of expression of the ATP-dependent stress protease Clp indicates that hyperosmolarity causes accumulation of misfolded proteins in both strains, and that GB-mediated restoration suppresses this intracellular stress in CIRM-BIA 129, yet not in CIRM-BIA 1025.

\subsection{Salt stress proteome is strain-dependent}

Our study clearly indicated that osmoadaptation is more efficiently induced by $\mathrm{NaCl}$ in CIRM-BIA 129 than in CIRM-BIA 1025. In hyperosmotic conditions, $P$. freudenreichii CIRM-BIA 1025, which failed to adapt to strong hyperosmotic constraint and to be protected by GB, overexpressed a different set of proteins. This included heat shock proteins Hsp20, which reflect intracellular macromolecules damages (Table 4). This also included proteins involved in intracellular detoxification such as aldo/keto reductase, as well as ribose-5-phosphate isomerase, which is involved in the pentose phosphate pathway, producing NADPH and remediating oxidative stress. Moreover, PLP-dependent cystathionase, with a cystathionine beta-lyase activity, which is involved in remediation of intracellular reactive metabolites spontaneously damaging macromolecules in Salmonella [53], was also induced by salt in CIRM-BIA 1025. Accordingly, PII nitrogen regulatory protein was strongly induced and plays a pivotal role in nitrogen stress remediation and stringent response [54,55]. Moreover, overexpression of chorismate mutase and of 3-phosphoshikimate 1-carboxyvinyltransferase indicate induction of the shikimate pathway, which is used to protect against reactive oxygen species (ROS) generated by salt stress in plants [56]. Such over-expressions were not correlated with crossprotection of the strain CIRM-BIA 1025 towards challenge tests, in contrast with CIRM-BIA 129. 
Table 3

Salt and glycine betaine-mediated modulation of proteins belonging to the COG functional category E " amino acid metabolism and transport".

\begin{tabular}{|c|c|c|c|c|c|c|c|}
\hline \multirow[t]{2}{*}{ Accession } & \multirow[t]{2}{*}{ Description $^{\mathrm{a}}$} & \multicolumn{3}{|l|}{ CIRM-BIA 129} & \multicolumn{3}{|c|}{ CIRM-BIA 1025} \\
\hline & & $\begin{array}{l}\mathrm{MMO}+ \\
\mathrm{NaCl} / \mathrm{MMO}^{\mathrm{b}}\end{array}$ & $\begin{array}{l}\mathrm{MMO}+ \\
\mathrm{NaCl}+\mathrm{GB} / \\
\mathrm{MMO}^{\mathrm{c}}\end{array}$ & $\begin{array}{l}\mathrm{MMO}+\mathrm{NaCL}+ \\
\mathrm{GB} / \mathrm{MMO}+ \\
\mathrm{NaCl}^{\mathrm{d}}\end{array}$ & $\begin{array}{l}\mathrm{MMO}+ \\
\mathrm{NaCl} / \mathrm{MMO}^{\mathrm{b}}\end{array}$ & $\begin{array}{l}\mathrm{MMO}+ \\
\mathrm{NaCl}+\mathrm{GB} / \\
\mathrm{MMO}^{\mathrm{c}}\end{array}$ & $\begin{array}{l}\mathrm{MMO}+\mathrm{NaCL}+ \\
\mathrm{GB} / \mathrm{MMO}+ \\
\mathrm{NaCl}^{\mathrm{d}}\end{array}$ \\
\hline emb|CDP48506.1| & Alanine dehydrogenase & 0,07 & $\mathrm{NS}^{\mathrm{e}}$ & 11,62 & $0,30 *$ & $0,32 *$ & NS \\
\hline emb|CDP48687.1| & Glycine cleavage H-protein (lipoate-binding) & 0,38 & 0,46 & NS & 0,51 & 0,57 & NS \\
\hline emb|CDP49124.1| & $\begin{array}{l}\text { Glutamine amidotransferase of anthranilate } \\
\text { synthase or para-aminobenzoate synthase }\end{array}$ & 0,45 & NS & 1,83 & NS & NS & NS \\
\hline emb|CEH00437.1| & Xaa-Pro aminopeptidase I & 0,48 & NS & 1,78 & NS & NS & NS \\
\hline emb|CDP48503.1| & Amidohydrolase & 0,53 & NS & 2,00 & NS & NS & NS \\
\hline emb|CDP48646.1| & anthranilate synthase component I & 0,57 & NS & NS & NS & NS & NS \\
\hline emb|CDP49409.1| & Glutamine synthetase & 0,59 & 1,51 & 2,56 & NS & NS & NS \\
\hline emb|CDP47865.1| & Cysteine synthase 1 & 0,60 & NS & NS & NS & NS & NS \\
\hline emb|CDP48633.1| & Histidinol-phosphate aminotransferase & 0,60 & NS & NS & NS & NS & NS \\
\hline emb|CDP48419.1| & 4-aminobutyrate aminotransferase & 0,61 & NS & NS & NS & NS & NS \\
\hline emb|CDP49173.1| & Dihydroxy-acid dehydratase & 0,62 & NS & NS & 0,62 & 0,62 & NS \\
\hline emb|CDP49134.1| & L-serine dehydratase & 0,63 & NS & NS & 0,62 & 0,62 & NS \\
\hline emb|CDP48561.1| & $\begin{array}{l}\text { polar amino acid } \mathrm{ABC} \text { transporter, binding } \\
\text { protein component }\end{array}$ & 0,65 & NS & NS & NS & NS & NS \\
\hline emb|CDP49308.1| & Cysteine desulphurases, SufS & 1,66 & NS & 0,61 & NS & NS & NS \\
\hline emb|CDP48772.1| & 3-isopropylmalate dehydratase small subunit & 1,66 & NS & 0,62 & NS & NS & NS \\
\hline emb|CDP49711.1| & Nitrogen regulatory protein P-II & $0,18^{*}$ & $2,16^{*}$ & $12,1^{*}$ & $4,41 *$ & $4,41^{*}$ & NS \\
\hline emb|CEG99164.1| & Alanine dehydrogenase & $0,36^{*}$ & NS & $2,57^{*}$ & 0,25 & 0,30 & NS \\
\hline emb|CEG98734.1| & Glutamate synthase large subunit (Ferredoxin) & $0,65^{*}$ & NS & NS & NS & NS & NS \\
\hline emb|CDP49001.1| & glutamate dehydrogenase & $0,65^{*}$ & NS & NS & NS & NS & NS \\
\hline emb|CEG99336.1| & Aminopeptidase N, Lysyl aminopeptidase & NS & 1,51 & NS & NS & NS & NS \\
\hline emb|CDP49614.1| & Argininosuccinate synthase & NS & 1,70 & 1,65 & NS & NS & NS \\
\hline emb|CEG97416.1| & Protein of unknown function & NS & NS & NS & NS & $0,50^{*}$ & NS \\
\hline emb $|\mathrm{CDP} 48480.1|$ & $\begin{array}{l}\text { Imidazole glycerol phosphate synthase } \\
\text { subunit HisF }\end{array}$ & NS & NS & NS & 1,50 & NS & NS \\
\hline emb|CDP47871.1| & Chorismate mutase & NS & 1,60 & NS & 2,36 & 3,08 & NS \\
\hline emb|CDP48779.1| & 3-isopropylmalate dehydrogenase & NS & 0,64 & NS & NS & NS & NS \\
\hline emb|CDP47561.1| & $\begin{array}{l}N \text {-acetyl-gamma-glutamyl-phosphate } \\
\text { reductase }\end{array}$ & NS & NS & 1,81 & NS & NS & NS \\
\hline emb|CDP49606.1| & Shikimate 5-dehydrogenase & NS & NS & NS & 0,66 & 0,67 & NS \\
\hline emb|CDP48345.1| & $\begin{array}{l}\text { Phosphoserine phosphatase/homoserine } \\
\text { phosphotransferase bifunctional protein }\end{array}$ & NS & NS & NS & 1,80 & 2,02 & NS \\
\hline emb|CEG98743.1| & Phosphoribosyl-AMP cyclohydrolase & NS & NS & NS & 0,46 & 0,44 & NS \\
\hline emb|CDP48360.1| & $\begin{array}{l}\text { 3-phosphoshikimate } 1 \text { - } \\
\text { carboxyvinyltransferase }\end{array}$ & NS & NS & NS & 1,52 & 1,60 & NS \\
\hline emb|CDP48589.1| & methionine synthase & NS & 2,11 & NS & NS & NS & NS \\
\hline emb|CDP47558.1| & $\begin{array}{l}\text { Acetylornithine and succinylornithine } \\
\text { aminotransferase }\end{array}$ & NS & NS & 1,75 & NS & NS & NS \\
\hline emb|CEG99593.1| & Aspartate ammonia-lyase (Aspartase) & NS & NS & 0,63 & NS & NS & NS \\
\hline emb $|\mathrm{CDP} 47560.1|$ & $\begin{array}{l}\text { Arginine biosynthesis bifunctional protein } \\
\text { ArgJ }\end{array}$ & NS & 1,59 & NS & NS & $1,70^{*}$ & NS \\
\hline emb $|\mathrm{CDP} 48567.1|$ & $\begin{array}{l}\text { Bifunctional PLP-dependent enzyme with } \\
\text { beta-cystathionase and maltose regulon } \\
\text { repressor activities }\end{array}$ & NS & NS & NS & 1,94 & 2,11 & NS \\
\hline emb|CDP49050.1| & Phosphoserine aminotransferase & NS & 0,54 & 0,44 & NS & NS & NS \\
\hline emb|CDP47562.1| & Aspartate aminotransferase & NS & NS & NS & 1,57 & 1,64 & NS \\
\hline emb|CEG98065.1| & Amino acid permease. Membrane protein & NS & NS & $2,81^{*}$ & NS & NS & NS \\
\hline emb|CEG99028.1| & $\begin{array}{l}\text { Amino acid permease-associated region. } \\
\text { Membrane protein }\end{array}$ & NS & NS & NS & 1,60 & NS & NS \\
\hline emb|CDP49113.1| & Propanediol utilization protein PduU & NS & NS & NS & NS & $12,00^{*}$ & NS \\
\hline emb|CEH00744.1| & Thiamine pyrophosphate enzyme & NS & NS & NS & 0,55 & 0,54 & NS \\
\hline emb|CDP47931.1| & $\begin{array}{l}\text { solute binding protein of the } \mathrm{ABC} \text { transport } \\
\text { system }\end{array}$ & NS & 0,63 & NS & NS & NS & NS \\
\hline emb|CEG97415.1| & $\begin{array}{l}\text { ATP-binding protein opuCA of Glycine } \\
\text { betaine/carnitine/choline ABC transporter }\end{array}$ & $1,65^{*}$ & NS & NS & NS & NS & NS \\
\hline emb|CDP47878.1| & $\begin{array}{l}\text { ATP-binding protein opuCA of Glycine } \\
\text { betaine/carnitine/choline ABC transporter }\end{array}$ & $1,68^{*}$ & NS & NS & NS & NS & NS \\
\hline emb|CEG97413.1| & binding protein of choline $\mathrm{ABC}$ transporter & $2,15^{*}$ & $1,63^{*}$ & NS & NS & NS & NS \\
\hline emb|CDP47876.1| & binding protein of choline $\mathrm{ABC}$ transporter & $2,34 *$ & $1,71 *$ & NS & NS & NS & NS \\
\hline
\end{tabular}

*Ratio were calculated with XIC methods, number with stars where calculated with peak counting method when XIC ratio was not available.

a Determined by using UniProtKB database corresponding to ...

b Ratio of the protein level in the $\mathrm{MMO}+\mathrm{NaCl}$ medium compared to MMO medium. This ratio indicates induction (ratio $>1.5$ ) or repression (ratio $>0.66$ ) by $\mathrm{NaCl}$.

c Ratio of the protein level in the $\mathrm{MMO}+\mathrm{NaCl}+\mathrm{GB}$ medium compared to MMO medium. This ratio indicates induction (ratio $>1.5$ ) or repression (ratio $>$ $0.66)$ by $\mathrm{NaCl}+\mathrm{GB}$.

d Ratio of the protein level in the $\mathrm{MMO}+\mathrm{NaCl}+\mathrm{GB}$ medium compared to $\mathrm{MMO}+\mathrm{NaCl}$ medium. This ratio indicates induction (ratio $>1.5$ ) or repression (ratio $>0.66$ ) by $\mathrm{NaCl}+\mathrm{GB}$.

e Non significant. 


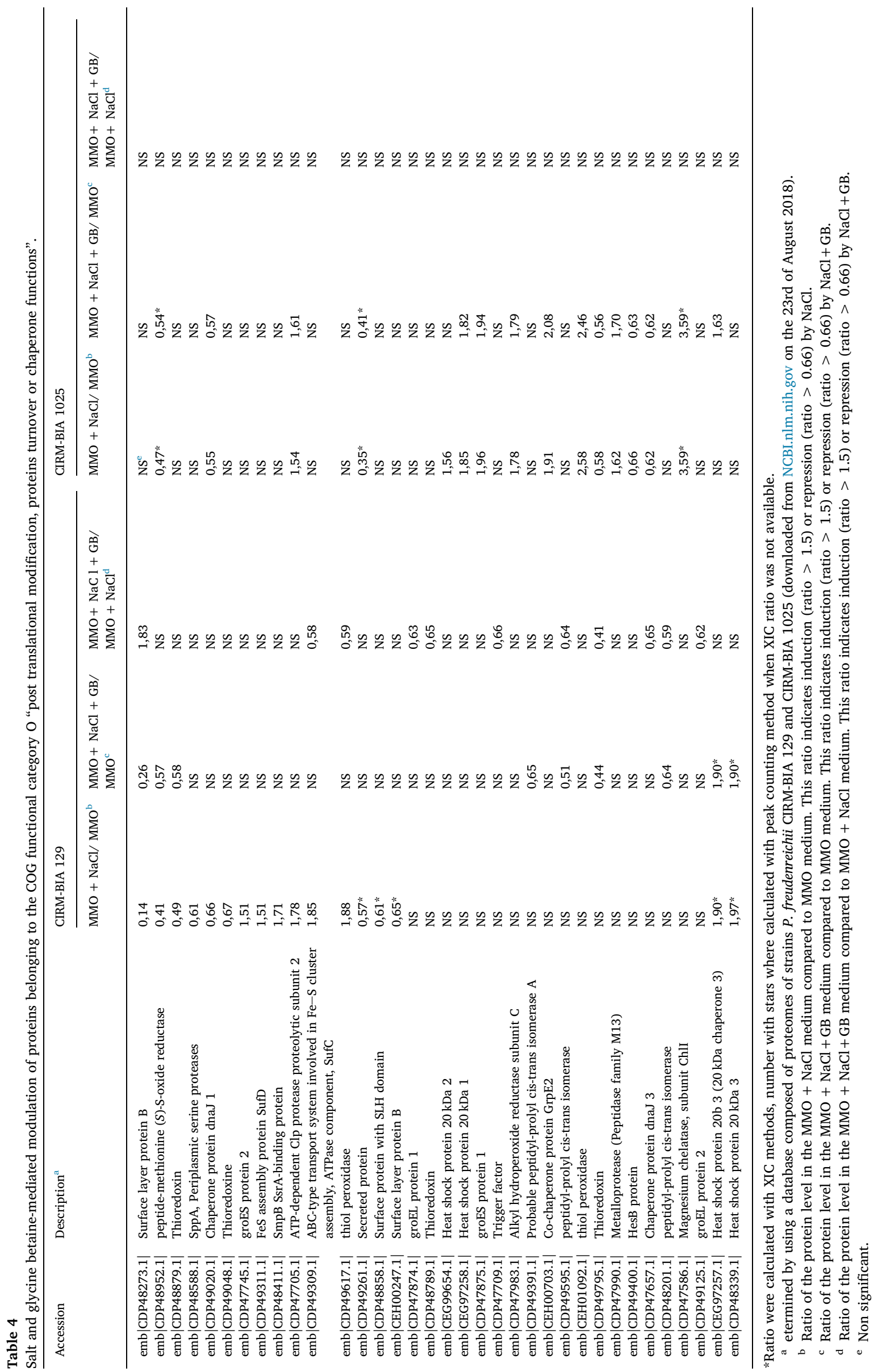


A

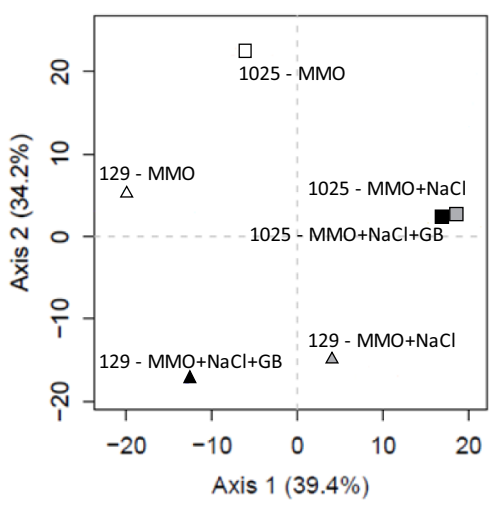

C

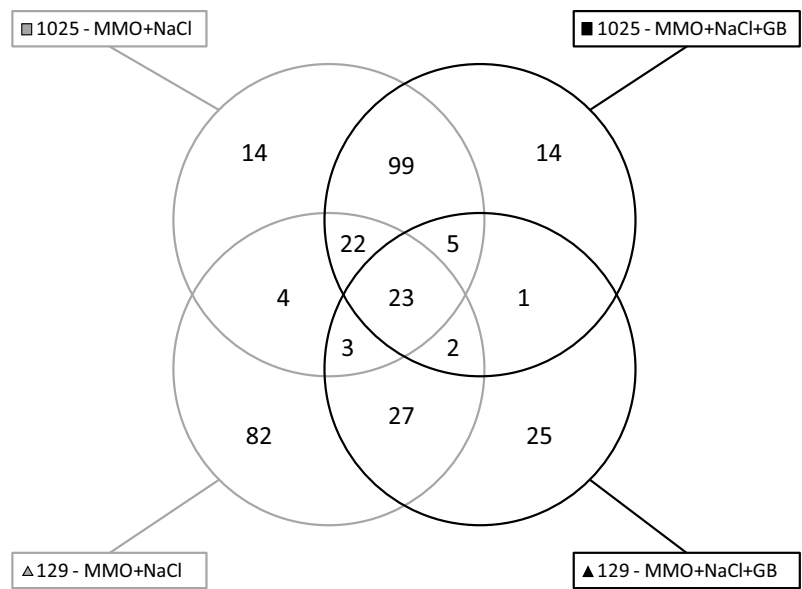

B

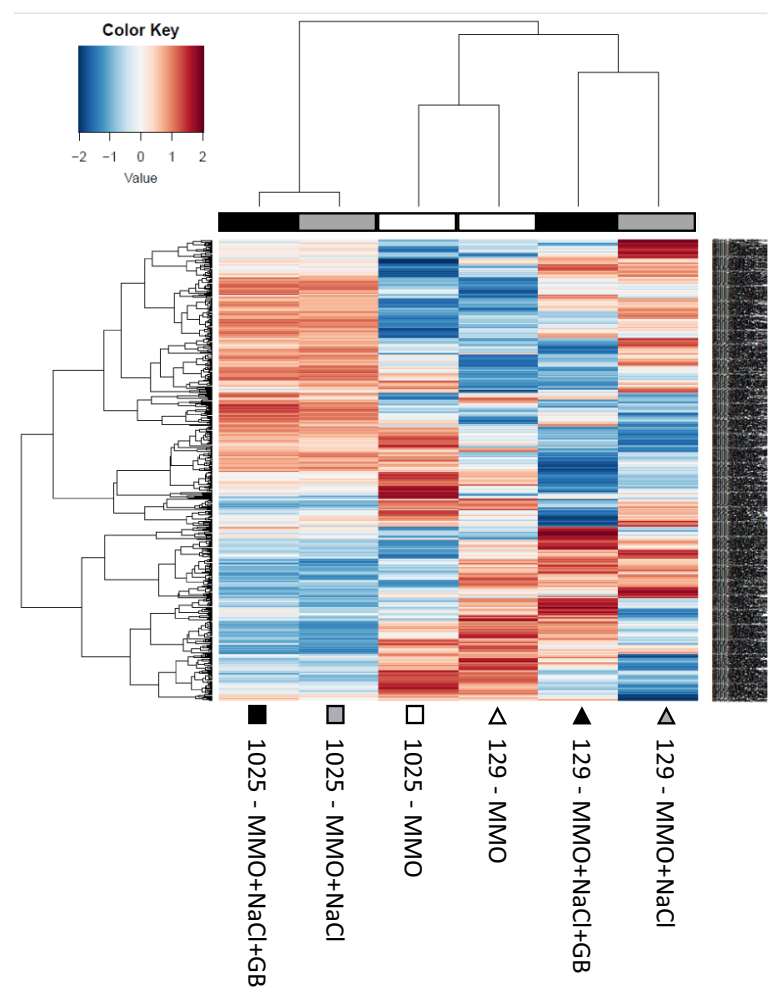

\section{Figure 4}

Fig. 4. Glycine betaine effect on the stress proteome is strain-dependent.

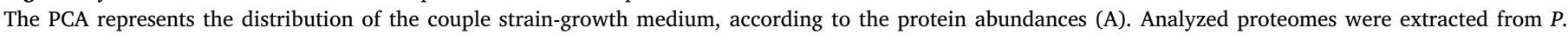

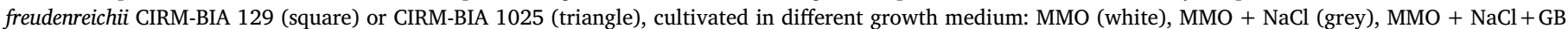

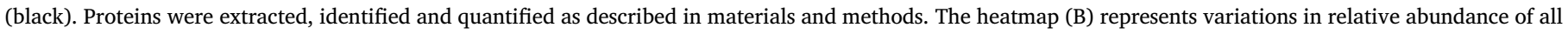
detected proteins, ranging from -2 (blue) to +2 (red).

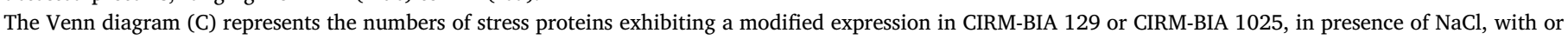

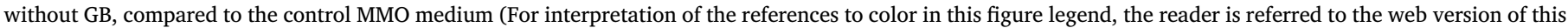
article.).

\section{P. freudenreichii CIRM-BIA 129}
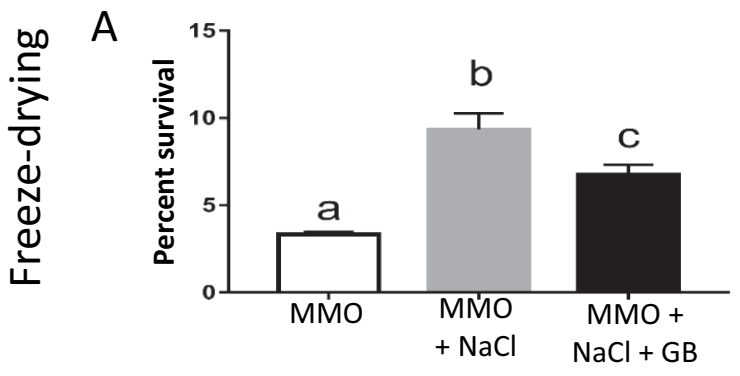

Growth medium
P. freudenreichii CIRM-BIA 1025

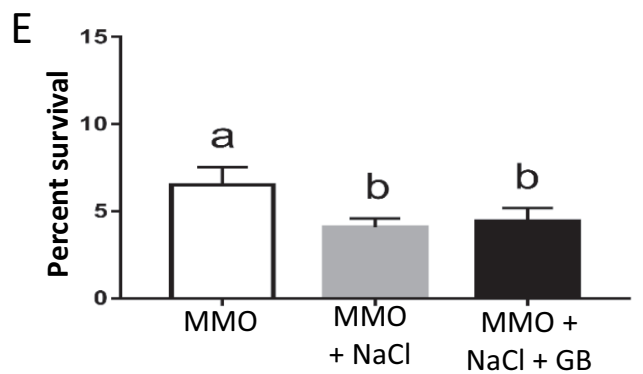

Growth medium

Fig. 5. Osmoadaptation modulates the viability of $P$. freudenreichii submitted to freeze-drying.

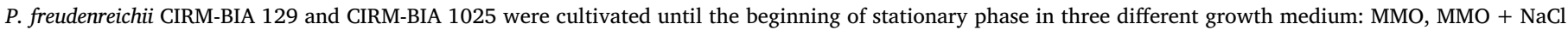

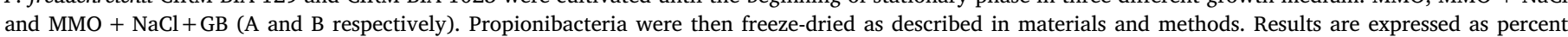

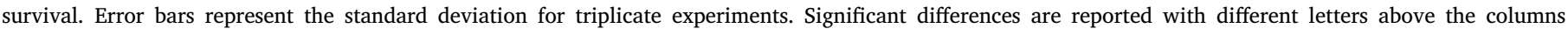
( $\mathrm{p}>.05)$. 


\section{Conclusion}

As a conclusion, this work highlights the strain-dependence of osmoadaptation, and of the resulting cross-protections, in $P$. freudenreichii. It confirms that strains selection is an important prerequisite to industrial production of bacteria. $P$. freudenreichii CIRM-BIA 129, which previously revealed a high probiotic potential, is able to adapt hyperosmotic conditions. Identification of relevant differential proteins provided new insights into strain-dependent osmotic adaptation. However, accumulation of GB, considered as universal osmoprotectant, has deleterious effects on stress tolerance in this strain. Finally, growth conditions constitute key parameters for freeze-drying optimization.

\section{Acknowledgements}

F. Gaucher is the recipient of a joint doctoral fellowship from Bioprox and from the French ANRT (Association Nationale de la Recherche et de la Technologie). Authors thank Eminem Hental for critical reading of the manuscript.

\section{Declaration of competing interests}

The authors have no conflict of interests to declare.

\section{Appendix A. Supplementary data}

Supplementary data to this article can be found online at https:// doi.org/10.1016/j.jprot.2019.103400.

\section{References}

1] F.J. Cousin, D.D.G. Mater, B. Foligne, G. Jan, Dairy propionibacteria as human probiotics: a review of recent evidence, Dairy Sci. Technol. (2010), https://doi.org/ $10.1051 /$ dst/2010032.

[2] H. Rabah, O. Ménard, F. Gaucher, F.L.R. do Carmo, D. Dupont, G. Jan, Cheese matrix protects the immunomodulatory surface protein SlpB of Propionibacterium freudenreichii during in vitro digestion, Food Res. Int. 106 (2018) 712-721, https://doi.org/10.1016/j.foodres.2018.01.035.

[3] $\mathrm{FAO} / \mathrm{WHO}$, Evaluation of health and nutritional properties of powder milk and live lactic acid bacteria, Food and Agriculture Organization of the United Nations and World Health Organization Expert Consultation Report, FAO, Rome, Italy, 2001.

[4] L.A. David, C.F. Maurice, R.N. Carmody, D.B. Gootenberg, J.E. Button, B.E. Wolfe, A.V. Ling, A.S. Devlin, Y. Varma, M.A. Fischbach, S.B. Biddinger, R.J. Dutton, P.J. Turnbaugh, Diet rapidly and reproducibly alters the human gut microbiome, Nature. 505 (2014) 559-563, https://doi.org/10.1038/nature12820.

[5] C. Plé, J. Breton, R. Richoux, M. Nurdin, S.-M. Deutsch, H. Falentin, C. Hervé, V. Chuat, R. Lemée, E. Maguin, G. Jan, M. Van de Guchte, B. Foligné, Combining selected immunomodulatory Propionibacterium freudenreichii and Lactobacillus delbrueckii strains: reverse engineering development of an anti-inflammatory cheese, Mol. Nutr. Food Res. 60 (2016) 935-948, https://doi.org/10.1002/mnfr. 201500580.

[6] J.C. Sniffen, L.V. McFarland, C.T. Evans, E.J.C. Goldstein, Choosing an appropriate probiotic product for your patient: an evidence-based practical guide, PLoS One 13 (2018) e0209205, , https://doi.org/10.1371/journal.pone.0209205.

[7] D. Bouglé, N. Roland, F. Lebeurrier, Effect of Propionibacteria supplementation on fecal Bifidobacteria and segmental colonic transit time in healthy human subjects, Scand. J. Gastroenterol. 34 (1999) 144-148, https://doi.org/10.1080/ 00365529950172998.

[8] K. Hojo, N. Yoda, H. Tsuchita, T. Ohtsu, K. Seki, N. Taketomo, T. Murayama, H. Iino, Effect of ingested culture of Propionibacterium freudenreichii ET-3 on fecal microflora and stool frequency in healthy females, Biosci. Microflora. 21 (2002) 115-120, https://doi.org/10.12938/bifidus1996.21.115.

[9] H. Rabah, F. Rosa do Carmo, G. Jan, Dairy Propionibacteria: versatile probiotics, Microorganisms. 5 (2017) 24, https://doi.org/10.3390/microorganisms5020024.

[10] B. Foligne, S.-M. Deutsch, J. Breton, F.J. Cousin, J. Dewulf, M. Samson, B. Pot, G. Jan, Promising immunomodulatory effects of selected strains of dairy Propionibacteria as evidenced in vitro and in vivo, Appl. Environ. Microbiol. 76 (2010) 8259-8264, https://doi.org/10.1128/AEM.01976-10.

[11] C. Plé, R. Richoux, J. Jardin, M. Nurdin, V. Briard-Bion, S. Parayre, S. Ferreira, B. Pot, G. Bouguen, S.-M. Deutsch, H. Falentin, B. Foligné, G. Jan, Single-strain starter experimental cheese reveals anti-inflammatory effect of Propionibacterium freudenreichii CIRM BIA 129 in TNBS-colitis model, J. Funct. Foods 18 (2015) 575-585, https://doi.org/10.1016/j.jff.2015.08.015.

[12] V. Gagnaire, J. Jardin, H. Rabah, V. Briard-Bion, G. Jan, Emmental cheese environment enhances Propionibacterium freudenreichii stress tolerance, PLoS One 10 (2015) e0135780, , https://doi.org/10.1371/journal.pone.0135780.
[13] S. Huang, M.-L. Vignolles, X.D. Chen, Y. Le Loir, G. Jan, P. Schuck, R. Jeantet, Spray drying of probiotics and other food-grade bacteria: a review, Trends Food Sci. Technol. 63 (2017) 1-17, https://doi.org/10.1016/j.tifs.2017.02.007.

[14] C. Santivarangkna, U. Kulozik, P. Foerst, Alternative drying processes for the in dustrial preservation of lactic acid starter cultures, Biotechnol. Prog. 23 (2007) 302-315, https://doi.org/10.1021/bp060268f.

[15] M.A. Golowczyc, C.L. Gerez, J. Silva, A.G. Abraham, G.L. De Antoni, P. Teixeira, Survival of spray-dried Lactobacillus kefir is affected by different protectants and storage conditions, Biotechnol. Lett. 33 (2011) 681-686, https://doi.org/10.1007/ s10529-010-0491-6.

[16] S. Huang, C. Cauty, A. Dolivet, Y. Le Loir, X.D. Chen, P. Schuck, G. Jan, R. Jeantet, Double use of highly concentrated sweet whey to improve the biomass production and viability of spray-dried probiotic bacteria, J. Funct. Foods 23 (2016) 453-463, https://doi.org/10.1016/j.jff.2016.02.050.

[17] R. Paéz, L. Lavari, G. Vinderola, G. Audero, A. Cuatrin, N. Zaritzky, J. Reinheimer, Effect of heat treatment and spray drying on lactobacilli viability and resistance to simulated gastrointestinal digestion, Food Res. Int. 48 (2012) 748-754, https://doi. org/10.1016/j.foodres.2012.06.018.

[18] F. Gaucher, S. Bonnassie, H. Rabah, P. Marchand, P. Blanc, R. Jeantet, G. Jan, Review: adaptation of beneficial Propionibacteria, lactobacilli, and Bifidobacteria improves tolerance toward technological and digestive stresses, Front. Microbiol. 10 (2019) 841, , https://doi.org/10.3389/fmicb.2019.00841.

[19] I. Mainville, Y. Arcand, E.R. Farnworth, A dynamic model that simulates the human upper gastrointestinal tract for the study of probiotics, Int. J. Food Microbiol. 99 (2005) 287-296, https://doi.org/10.1016/j.ijfoodmicro.2004.08.020.

[20] J. De Dea Lindner, C. Canchaya, Z. Zhang, E. Neviani, G.F. Fitzgerald, D. van Sinderen, M. Ventura, Exploiting Bifidobacterium genomes: the molecular basis of stress response, Int. J. Food Microbiol. 120 (2007) 13-24, https://doi.org/10.1016/ j.ijfoodmicro.2007.06.016

[21] A.S. Carvalho, J. Silva, P. Ho, P. Teixeira, F.X. Malcata, P. Gibbs, Relevant factors for the preparation of freeze-dried lactic acid bacteria, Int. Dairy J. 14 (2004) 835-847, https://doi.org/10.1016/j.idairyj.2004.02.001.

[22] C. Desmond, C. Stanton, G.F. Fitzgerald, K. Collins, R. Paul Ross, Environmental adaptation of probiotic lactobacilli towards improvement of performance during spray drying, Int. Dairy J. 11 (2001) 801-808, https://doi.org/10.1016/S09586946(01)00121-2.

[23] C. Li, J.-L. Zhao, Y.-T. Wang, X. Han, N. Liu, Synthesis of cyclopropane fatty acid and its effect on freeze-drying survival of Lactobacillus bulgaricus L2 at different growth conditions, World J. Microbiol. Biotechnol. 25 (2009) 1659-1665, https:// doi.org/10.1007/s11274-009-0060-0.

[24] J. Silva, A.S. Carvalho, R. Ferreira, R. Vitorino, F. Amado, P. Domingues, P. Teixeira, P.A. Gibbs, Effect of the $\mathrm{pH}$ of growth on the survival of Lactobacillus delbrueckii subsp. bulgaricus to stress conditions during spray-drying, J. Appl. Microbiol. 98 (2005) 775-782, https://doi.org/10.1111/j.1365-2672.2004. 02516.x.

[25] J.R. Broadbent, R.L. Larsen, V. Deibel, J.L. Steele, Physiological and transcriptional response of Lactobacillus casei ATCC 334 to acid stress, J. Bacteriol. 192 (2010) 2445-2458, https://doi.org/10.1128/JB.01618-09.

[26] G. Jan, P. Leverrier, I. Proudy, N. Roland, Survival and beneficial effects of propionibacteria in the human gut: in vivo and in vitro investigations, Lait 82 (2002) 131-144, https://doi.org/10.1051/lait:2001012.

[27] P. Leverrier, D. Dimova, V. Pichereau, Y. Auffray, P. Boyaval, G. Jan, Susceptibility and adaptive response to bile salts in Propionibacterium freudenreichii: physiological and proteomic analysis, Appl. Environ. Microbiol. 69 (2003) 3809-3818, https://doi.org/10.1128/AEM.69.7.3809-3818.2003.

[28] P. Leverrier, J.P.C. Vissers, A. Rouault, P. Boyaval, G. Jan, Mass spectrometry proteomic analysis of stress adaptation reveals both common and distinct response pathways in Propionibacterium freudenreichii, Arch. Microbiol. 181 (2004) 215-230, https://doi.org/10.1007/s00203-003-0646-0.

[29] S. Huang, H. Rabah, J. Jardin, V. Briard-Bion, S. Parayre, M.-B. Maillard, Y. Le Loir, X.D. Chen, P. Schuck, R. Jeantet, G. Jan, Hyperconcentrated sweet whey, a new culture medium that enhances Propionibacterium freudenreichii stress tolerance, Appl. Environ. Microbiol. 82 (2016) 4641-4651, https://doi.org/10.1128/AEM. 00748-16.

[30] K. Papadimitriou, Á. Alegría, P.A. Bron, M. de Angelis, M. Gobbetti, M. Kleerebezem, J.A. Lemos, D.M. Linares, P. Ross, C. Stanton, F. Turroni, D. van Sinderen, P. Varmanen, M. Ventura, M. Zúñiga, E. Tsakalidou, J. Kok, Stress physiology of lactic acid bacteria, Microbiol. Mol. Biol. Rev. 80 (2016) 837-890, https://doi.org/10.1128/MMBR.00076-15.

[31] L.N. Csonka, Physiological and genetic responses of bacteria to osmotic stress, Microbiol. Rev. 53 (1989) 121-147.

[32] L.N. Csonka, A.D. Hanson, Prokaryotic osmoregulation: genetics and physiology, Annu. Rev. Microbiol. 45 (1991) 569-606, https://doi.org/10.1146/annurev.mi. 45.100191.003033.

[33] E. Kets, P. Teunissen, J. de Bont, Effect of Compatible Solutes on Survival of Lactic Acid Bacteria Subjected to Drying, (1996), pp. 259-261.

[34] E. Glaasker, W.N. Konings, B. Poolman, Osmotic regulation of intracellular solute pools in Lactobacillus plantarum, J. Bacteriol. 178 (1996) 575-582.

[35] F.S. Cardoso, R.F. Castro, N. Borges, H. Santos, Biochemical and genetic characterization of the pathways for trehalose metabolism in Propionibacterium freudenreichii, and their role in stress response, Microbiology. 153 (2007) 270-280, https://doi.org/10.1099/mic.0.29262-0.

[36] G. Jan, A. Rouault, J.-L. Maubois, Acid stress susceptibility and acid adaptation of Propionibacterium freudenreichii subsp. shermanii, Lait 80 (2000) 325-336, https:// doi.org/10.1051/lait:2000128.

[37] A.C. Malik, G.W. Reinbold, E.R. Vedamuthu, An evaluation of the taxonomy of 
Propionibacterium, Can. J. Microbiol. 14 (1968) 1185-1191.

[38] G. Gouesbet, C. Blanco, J. Hamelin, T. Bernard, Osmotic adjustment in Brevibacterium ammoniagenes: pipecolic acid accumulation at elevated osmolalities, J. Gen. Microbiol. 138 (1992) 959-965, https://doi.org/10.1099/00221287138-5-959.

[39] P. Leverrier, Susceptibilité et adaptation de Propionibacterium freudenreichii aux stress digestifs, (2003).

[40] M. Serata, M. Kiwaki, T. Iino, Functional analysis of a novel hydrogen peroxide resistance gene in Lactobacillus casei strain Shirota, Microbiology. 162 (2016) 1885-1894, https://doi.org/10.1099/mic.0.000379.

[41] S. Huang, F. Gaucher, C. Cauty, J. Jardin, Y. Le Loir, R. Jeantet, X.D. Chen, G. Jan, Growth in hyper-concentrated sweet whey triggers multi stress tolerance and spray drying survival in Lactobacillus casei BL23: from the molecular basis to new perspectives for sustainable probiotic production, Front. Microbiol. 9 (2018) 2548, https://doi.org/10.3389/fmicb.2018.02548 eCollection 2018.

[42] M. Blein-Nicolas, W. Albertin, T. da Silva, B. Valot, T. Balliau, I. Masneuf-Pomarède, M. Bely, P. Marullo, D. Sicard, C. Dillmann, D. de Vienne, M. Zivy, A systems approach to elucidate Heterosis of protein abundances in yeast, Mol. Cell. Proteomics 14 (2015) 2056-2071, https://doi.org/10.1074/mcp.M115.048058.

[43] M. Dalmasso, J. Aubert, S. Even, H. Falentin, M.-B. Maillard, S. Parayre, V. Loux, J. Tanskanen, A. Thierry, Accumulation of intracellular glycogen and trehalose by Propionibacterium freudenreichii under conditions mimicking cheese ripening in the cold, Appl. Environ. Microbiol. 78 (2012) 6357-6364, https://doi.org/10. 1128/AEM.00561-12.

[44] F.S. Cardoso, P. Gaspar, J. Hugenholtz, A. Ramos, H. Santos, Enhancement of trehalose production in dairy propionibacteria through manipulation of environmental conditions, Int. J. Food Microbiol. 91 (2004) 195-204, https://doi.org/10.1016/ S0168-1605(03)00387-8.

[45] C. Santivarangkna, B. Higl, P. Foerst, Protection mechanisms of sugars during different stages of preparation process of dried lactic acid starter cultures, Food Microbiol. 25 (2008) 429-441, https://doi.org/10.1016/j.fm.2007.12.004.

[46] M.-J. Chen, H.-Y. Tang, M.-L. Chiang, Effects of heat, cold, acid and bile salt adaptations on the stress tolerance and protein expression of kefir-isolated probiotic Lactobacillus kefiranofaciens M1, Food Microbiol. 66 (2017) 20-27, https://doi. org/10.1016/j.fm.2017.03.020.
[47] Y. Weng, F. Chen, Y. Liu, Q. Zhao, R. Chen, X. Pan, C. Liu, Z. Cheng, S. Jin, Y. Jin, W. Wu, Pseudomonas aeruginosa enolase influences bacterial tolerance to oxidative stresses and virulence, Front. Microbiol. 7 (2016), https://doi.org/10.3389/fmicb. 2016.01999.

[48] N. Guan, L. Liu, H. Shin, R.R. Chen, J. Zhang, J. Li, G. Du, Z. Shi, J. Chen, Systems level understanding of how Propionibacterium acidipropionici respond to propionic acid stress at the microenvironment levels: mechanism and application, J. Biotechnol. 167 (2013) 56-63, https://doi.org/10.1016/j.jbiotec.2013.06.008.

[49] T. Hoffmann, A. Wensing, M. Brosius, L. Steil, U. Volker, E. Bremer, Osmotic control of opuA expression in Bacillus subtilis and its modulation in response to intracellular Glycine betaine and proline pools, J. Bacteriol. 195 (2013) 510-522, https://doi.org/10.1128/JB.01505-12.

[50] B. Poolman, J.J. Spitzer, J.M. Wood, Bacterial osmosensing: roles of membrane structure and electrostatics in lipid-protein and protein-protein interactions, Biochim. Biophys. Acta Biomembr. 1666 (2004) 88-104, https://doi.org/10.1016/ j.bbamem.2004.06.013.

[51] J.M. Wood, Osmosensing by bacteria: signals and membrane-based sensors, Microbiol, Mol. Biol. Rev. 63 (1999) 230-262.

[52] M.C. Pilonieta, T.A. Nagy, D.R. Jorgensen, C.S. Detweiler, A glycine betaine importer limits Salmonella stress resistance and tissue colonization by reducing trehalose production: Trehalose accumulation limits bacterial colonization, Mol. Microbiol. 84 (2012) 296-309, https://doi.org/10.1111/j.1365-2958.2012. 08022.x.

[53] D.C. Ernst, M.R. Christopherson, D.M. Downs, Increased activity of cystathionine $\beta$ Lyase suppresses 2-Aminoacrylate stress in Salmonella enterica, J. Bacteriol. 200 (2018), https://doi.org/10.1128/JB.00040-18.

[54] M. Merrick, Post-translational modification of PII signal transduction proteins, Front. Microbiol. 5 (2015), https://doi.org/10.3389/fmicb.2014.00763.

[55] D.R. Brown, G. Barton, Z. Pan, M. Buck, S. Wigneshweraraj, Nitrogen stress response and stringent response are coupled in Escherichia coli, Nat. Commun. 5 (2014), https://doi.org/10.1038/ncomms5115.

[56] S.J. Lee, E.-M. Jeong, A.Y. Ki, K.-S. Oh, J. Kwon, J.-H. Jeong, N.-J. Chung, Oxidative defense metabolites induced by salinity stress in roots of Salicornia herbacea, J. Plant Physiol. 206 (2016) 133-142, https://doi.org/10.1016/j.jplph.2016.08.015. 